\title{
Corporate Governance and Firm Value: International Evidence*
}

\author{
Manuel Ammann $^{\mathrm{a}}$, David Oesch ${ }^{\mathrm{a}, \mathrm{b}}$, and Markus M. Schmid ${ }^{\mathrm{c}, \#}$ \\ ${ }^{\mathrm{a}}$ Swiss Institute of Banking and Finance, University of St. Gallen, CH-9000 St. Gallen, \\ Switzerland \\ ${ }^{\mathrm{b}}$ Department of Finance, Stern School of Business, New York University, \\ New York, NY 10012, USA \\ ${ }^{\mathrm{c}}$ University of Mannheim, Finance Area, D-68131 Mannheim, Germany
}

This version: October 2010

\begin{abstract}
In this paper, we investigate the relation between firm-level corporate governance and firm value based on a large and previously unused dataset from Governance Metrics International (GMI) comprising 6,663 firm-year observations from 22 developed countries over the period from 2003 to 2007. Based on a set of 64 individual governance attributes we construct two alternative additive corporate governance indices with equal weights attributed to the governance attributes and one index derived from a principal component analysis. For all three indices we find a strong and positive relation between firm-level corporate governance and firm valuation. In addition, we investigate the value relevance of governance attributes that document the companies' social behavior. Regardless of whether these attributes are considered individually or aggregated into indices, and even when "standard" corporate governance attributes are controlled for, they exhibit a positive and significant effect on firm value. Our findings are robust to alternative calculation procedures for the corporate governance indices and to alternative estimation techniques.
\end{abstract}

Keywords: Corporate governance, Firm valuation, Minimum standards, Principal component analysis, Corporate social responsibility

JEL Classification: G32, G34, G38

\footnotetext{
* We are grateful to Howard Sherman from GMI for providing us with the dataset used in this study, and to Hubert de la Bruslerie, Günther Franke, Daniel Hoechle, Jens Jackwerth, Alexander Kohler, Dennis Mueller, Franz Palm (the editor), Thomas Poulsen, Cornelius Schmidt, Paul Söderlind, René Stulz, Rico von Wyss, two anonymous referees and an associate editor, and seminar participants at the University of St. Gallen, the University of Konstanz, the 2008 European Financial Management Association annual meetings, the 8th Swiss Doctoral Workshop in Finance in Gerzensee, the 2009 UBS Socially Responsible Investments conference in London, and the $10^{\text {th }}$ Workshop on Corporate Governance and Investment at Copenhagen Business School for useful comments. Financial support from the Swiss National Science Foundation is gratefully acknowledged.

${ }^{\#}$ Corresponding author: Tel.: +49-621-181-37-54; E-mail: schmid@bwl.uni-mannheim.de.

Address: University of Mannheim, Finance Area, Chair for Business Administration and Corporate Governance, D-68131 Mannheim, Germany.
} 


\section{Introduction}

Agency problems, and therefore good corporate governance helping to overcome them, may affect firm value in two different ways. First, good corporate governance may lead to high stock price multiples as investors anticipate that less cash flows will be diverted and a higher fraction of the firm's profits will come back to them as interest or dividends (Jensen and Meckling, 1976; La Porta et al., 2002). Second, good corporate governance may reduce the expected return on equity to the extent that it reduces shareholders' monitoring and auditing costs, leading to lower costs of capital (Shleifer and Vishny, 1997). However, it is not unequivocally clear that better governance is in fact related to higher company valuations as the costs associated with the implementation of stronger governance mechanisms may outweigh the benefits (e.g., Gillan et al., 2003; Chhaochharia and Grinstein, 2007; Bruno and Claessens, 2010).

The majority of the prior literature on the relation between corporate governance and firm value, documents that a stronger corporate governance is associated with a higher firm valuation (e.g., Yermack, 1996, Gompers et al., 2003, Cremers and Nair, 2005, Core et al., 2006, or Bebchuck et al., 2009). While much of this literature deals with specific aspects of corporate governance, such as ownership or board structure, part of the literature aggregates individual corporate governance attributes to corporate governance indices. For the U.S., a number of studies (e.g., Gompers et al., 2003; Bebchuck and Cohen, 2005; Bebchuck et al., 2009) demonstrate the value-relevance of such governance indices aggregating a number of firm-level governance attributes. Relatively few studies investigate the valuation impact of firm-level corporate governance practices in an international context, notable exceptions being La Porta et al. (2002), Klapper and Love (2004), Durnev and Kim (2005), and Francis et al. (2005). However, these studies use data compiled by La Porta et al. (1998) on minority shareholder rights protection, CLSA (Credit Lyonnais Securities Asia) scores, whose useful- 
ness has been questioned by Khanna et al. (2006) for example, or governance attributes related to disclosure only as measured by Standard \& Poor's rankings. To overcome the problem of data availability, some studies use hand-collected and survey-based datasets on the firms' corporate governance structure within one specific country. For example, Drobetz et al. (2004), Beiner et al. (2006), Black et al. (2006), and Balasubramaniam et al. (2009) document a positive relationship between governance practices and firm valuation for German, Swiss, Korean, and Indian public firms, respectively.

With the emergence of more detailed information on firm-level corporate governance for large samples of firms from multiple countries, a new stream of research has emerged. Aggarwal et al. (2009), for example, use data from RiskMetrics (formerly Institutional Shareholder Services (ISS)) and compare the governance of non-U.S. firms with a matched set of U.S. firms and find that the valuation of non-U.S. firms falls as their governance index value decreases as compared to the governance index of matching U.S. firms. Bruno and Claessens (2010) also use ISS data and find that firm value depends on both country-level shareholder protection laws and firm-level corporate governance attributes. In addition, these relations are more pronounced in companies that depend on external financing. Chhaochharia and Laeven (2009), also using the ISS database, distinguish between governance attributes that are legally required and attributes that are adopted voluntarily. They show that firms that voluntarily adopt a more rigorous corporate governance structure are rewarded with a higher firm value. ${ }^{1}$

In this paper, we provide new evidence on the relationship between firm-level corporate governance and company valuation in an international setting. We contribute to the literature by using a new and previously unexplored dataset from Governance Metrics International (GMI). Using a new dataset is important as the quality of corporate governance data has been questioned (e.g., Khanna et al., 2006) and a check of prior results based on a new dataset pro-

\footnotetext{
${ }^{1}$ Aggarwal and Williamson (2006) and Brown and Caylor (2006) use the ISS database to construct governance indices for U.S. firms only and both find a positive relation between corporate governance and firm value.
} 
vides an important "out-of-sample" test. Our GMI dataset covers 22 developed countries (excluding the U.S.) around the world over the time period from 2003 to 2007 . The governance data we use is much richer than the datasets used in prior studies. It covers 64 different governance attributes classified by GMI in six categories, namely board accountability, financial disclosure and internal control, shareholder rights, remuneration, market for control, and corporate behavior. One benefit emerging from the breath of our database is that we are able to investigate the valuation effect of specific governance attributes that document a company's social behavior, also termed "corporate social responsibility (CSR)". To our knowledge, there are only three previous studies that investigate whether a company's CSR has an impact on firm value when standard corporate governance attributes are accounted for (Fisman, Heal, and Nair, 2006; Harjoto and Jo, 2008; Barnea and Rubin, 2010). ${ }^{2}$ Another advantage of our GMI dataset is that it contains the longest panel used in international studies on the valuation effect of firm-level corporate governance so far. Aggarwal et al. (2009) and Bruno and Claessens (2010) use purely cross-sectional datasets and Chhaochharia and Laeven (2009) a three-year panel dataset. Our five-year panel covering the time period from 2003 to 2007 has two major advantages. First, our sample size is substantially larger than that of Aggarwal et al. (2009) and Bruno and Claessens (2010) and similar to that of Chhaochharia and Laeven (2009) even though our dataset does not include any U.S. firms which account for approximately 1,500 observations (20\%) of Chhaochharia and Laeven's (2009) sample. Second, the longer time-series enables us to better investigate the dynamics of the relation between corporate governance and firm value and thereby accounting for the endogeneity of corporate governance in a dynamic panel GMM approach.

\footnotetext{
${ }^{2}$ A common problem in all these studies is that the measure of CSR, obtained from the Kinder, Lydenberg, and Domini's (KLD) Socrates database, is binary and only indicates whether a firm invests in CSR or not. Moreover, only Harjoto and Jo (2008) account for the endogeneity of CSR and none of the studies attempt to simultaneously account for the endogeneity of corporate governance.
} 
Even though there is an extensive literature investigating the relationship between corporate governance and firm value, there is still no consensus on how to measure corporate governance (e.g., Larcker et al., 2007; Ertugrul and Hegde, 2009). Besides using a new dataset, we contribute to the literature by testing alternative and distinct approaches on how to condense the large number of governance variables contained in our database into one measure of corporate governance. Prior literature almost exclusively uses additive indices giving mostly equal weights to each considered governance attribute. Besides using two alternative additive approaches to construct a governance index, we rely on principal component analysis (PCA) to condense the information content of a large number of variables into a small and tractable number of governance indices as recently proposed by Larcker et al. (2007). The first of the two additive approaches we use is based on Aggarwal et al. (2009) and Chhaochharia and Laeven (2009). To construct this index, we first determine the number of governance attributes with data available for each firm-year observation and then define the governance index as the percentage of attributes a particular company has in place. The second additive approach employs a very similar procedure but treats a governance attribute for which there is no information as if this attribute was not in place, instead of omitting such missing observations from the index construction. If firms are more likely to disclose information on governance attributes that are adopted, we would expect a stronger valuation effect of this second index as compared to the first one. The third alternative index, which uses PCA and is based on Larcker et al. (2007), condenses the information contained in the individual governance attributes into a smaller number of governance indices by finding the linear combinations of the original governance attributes that account for as much variation in the original dataset as possible. Hence, the weighting scheme in this third index is based on a statistical procedure instead of using equal or arbitrarily chosen weights. 
Our results indicate a strong and positive relation between firm-level corporate governance and firm valuation. These results are robust to alternative calculation procedures for the corporate governance indices, a breakdown of the sample by calendar year, and alternative estimation techniques. Moreover, we show that governance attributes documenting a company's social behavior also have a significantly positive effect on firm value, regardless of whether these variables are studied individually or aggregated to governance indices. The value relevance of these attributes is also robust to controlling for the effect of standard corporate governance attributes and different approaches to index calculation. When additionally including an interaction term between corporate governance and CSR, we find that the positive valuation effect of CSR is restricted to firms with a good corporate governance structure. Hence, a good corporate governance seems to assure that CSR expenditures are profitoriented rather than serving the managers' personal ambitions, for example to improve their reputation as good global citizens.

To release the assumption underlying our fixed effects panel regressions that all the unobserved heterogeneity that leads to the correlation between the corporate governance variables and the error term is constant over time we estimate a dynamic panel GMM estimator as proposed by Wintoki et al. (2008). This approach additionally alleviates the problem of slowly moving corporate governance indices over time, thus rendering fixed effects techniques ineffective (e.g., Coles et al., 2007). The results turn out to be robust and indicate a causal link between our three alternative corporate governance indices and firm value.

Finally, we investigate the economic importance of the valuation effect of corporate governance. The majority of previous research focuses on the statistical rather than the economic significance. Hence, there is little guidance from academic research on how large the potential valuation benefits associated with a good corporate governance in fact are. We show that, when using a similar approach to construct the corporate governance index as in Ag- 
garwal et al. (2009) and Chhaochharia and Laeven (2009), we find a similar valuation effect of corporate governance. Specifically, we find that a one standard deviation increase in the first additive governance index is associated with an increase in Tobin's Q of about 0.06 which corresponds to $3.5 \%(4.2 \%)$ of mean (median) Q in our sample. However, the economic significance of the valuation effect strongly depends on how the index is constructed. In particular, when we account for the fact that companies are more likely to report information on corporate governance attributes they have adopted or when we focus on changes in the governance scores which are truly firm-specific and not influenced by country-specific differences in legal regimes, the economic importance of the valuation effect substantially increases. In contrast, the magnitude of the valuation effect is virtually unaffected by the estimation methodology and remains similar in size even when we account for a potential endogeneity of corporate governance in a dynamic panel GMM setup.

The remainder of the paper is organized as follows. Section 2 describes the data, defines our variables, and explains the construction of our governance indices. Section 3 presents the main results. Section 4 contains robustness tests and extensions. Section 5 concludes.

\section{Data and Variables}

In this section, we first describe the corporate governance data used in our study. We then show how we aggregate the individual governance attributes to construct different corporate governance indices. Finally, we describe the financial data we use to construct the control variables used for the tests in the empirical section.

\section{1 Firm-level data on corporate governance attributes}

We use firm-level data on corporate governance attributes provided by Governance Metrics International (GMI). GMI started providing data on firm-level governance in 2003. It collects data on both U.S. and non-U.S. firms fully covering the MSCI World and the MSCI 
EAFE Index. GMI produces a governance rating for the covered firms using a proprietary scoring algorithm. To construct these ratings (which are not used in this study), GMI gathers information on individual governance attributes. These individual governance attributes are used for the construction of our governance indices. The starting point of our sample are all 7,092 non-U.S. firm-year observations on roughly 2,300 firms over the full sample period from 2003 to 2007 . The panel is unbalanced as the number of firms grows considerably over time (from 605 in 2003 to 2,215 in 2007). We drop countries with less than 10 firm-year observations in total (i.e., Argentina, Colombia, Czech Republic, Egypt, Hungary, Iceland, Israel, Jordan, Morocco, Pakistan, Peru, Philippines, Thailand, and Venezuela) as well as developing and emerging countries (i.e., Brazil, Chile, China, India, Indonesia, Malaysia, Mexico, Russia, South Africa, South Korea, Taiwan, and Turkey) as the valuation effect of firm-level corporate governance attributes may substantially differ between developed and developing countries. ${ }^{3}$ These sample restrictions leave us with a sample of 6,663 firm-year observations. Table 1 shows the distribution of firm-year observations across the 22 countries included in our sample. We see that the countries with the largest number of firm-year observations are Japan (1,762), UK (1,407), and Canada (471), while Portugal (45) and New Zealand (45) have the smallest number of firm-year observations.

We use a sample of 64 governance attributes that have been compiled by GMI. For each of these attributes, GMI assesses whether a firm attains a minimum level of implementation. The 64 attributes we consider are sub-categorized by GMI into 1) board accountability, 2) financial disclosure and internal control, 3) shareholder rights, 4) remuneration, 5) market for control, and 6) corporate behavior. Table 2 provides an overview of the 64 governance attributes and shows the percentage of firms meeting these criteria according to GMI's thresholds. The two studies most comparable to ours, both using ISS / RiskMetrics data for an interna-

\footnotetext{
${ }^{3}$ Klapper and Love (2004), for example, show that firm-level corporate governance matters more in countries with weak legal environments and argue that firms can partially compensate for ineffective laws and enforcement.
} 
tional sample of firms headquartered in developed countries, use 17 (Chhaochharia and Laeven, 2009) and 44 (Aggarwal et al., 2009) attributes, respectively. The most notable difference between our GMI dataset and these datasets from RiskMetrics is that GMI includes nine governance attributes that document a company's corporate social responsibility (CSR) behavior. Moreover, GMI provides more attributes in the category of financial disclosure and internal control. While our study includes eight attributes in this category, Aggarwal et al. (2009) and Chhaochharia and Laeven (2009) use only two and one attributes, respectively. In the other four categories, our dataset includes between three (shareholder rights and market for corporate control) and eight (remuneration) attributes that are not included in Aggarwal et al. (2009). The large difference in the remuneration category is mainly due to the fact that the attributes related to remuneration (and ownership) differ between the two databases. ${ }^{4}$

Various of the 64 governance attributes are met by the majority of sample firms. For example, seven of the 20 attributes pertaining to board accountability are fulfilled by over 80 percent of the firms in our sample. These attributes are: board performance is periodically evaluated, the board or a committee is responsible for CEO succession planning, the company has not failed to adopt the recommendations of a majority-approved shareholder proposal, the company has a separated chairman and CEO, all board members attended at least $75 \%$ of the board meetings, the number of shares held by officers and directors has not decreased by $10 \%$ or more over the last year, and the board has more than five but less than 16 directors. For the attributes on financial disclosure and internal control, five of the eight attributes are met by more than $80 \%$ of the firms in our sample: the company has not had a material earnings restatement in the past three years, the company has not received a qualified audit opinion within the last two fiscal years, the company is not currently under investigation for accounting

\footnotetext{
${ }^{4}$ The 17 attributes in Chhaochharia and Laeven (2009) are basically a sub-set of the 44 attributes in Aggarwal et al. (2009) as 16 of them are included in the latter study. Chhaochharia and Laeven (2009) do not include any attributes related to compensation and ownership and very few attributes related to the board of directors as compared to Aggarwal et al. (2009) and our study.
} 
irregularities, someone other than senior management has the sole authority to hire the outside auditor, and the company did not pay its auditor less for audit related services than for other services. In the category shareholder rights attributes, more than $90 \%$ of the firms allow shareholders to convene an EGM with $10 \%$ or less of the shares requesting one and do not cap voting rights at a certain percentage. More than $90 \%$ of the firms included in our sample meet five of the 12 governance criteria on remuneration: the CEO is without an employment agreement that provides for guaranteed bonus payments, the $\mathrm{CEO} /$ managing director does not sit on the remuneration committee, the company has neither repriced outstanding executive stock options nor used an option exchange program, and the dilution resulting from stock options that have been granted does not exceed $20 \%$. For the governance attributes on the market for corporate control, there is only one attribute that more than $90 \%$ of the companies in our sample fulfill, which is the absence of a shareholder rights plan ("poison pill"). Finally, for the attributes on corporate behavior, only two requirements (disclosure of a company's workplace safety record and disclosure of the company's policy regarding political donations) are met by less than $50 \%$. A comparison of Table 2 with commensurate results from studies using the ISS database such as, for example, Aggarwal et al. (2009) reveals that the level of implementation of governance attributes is similar for the governance attributes provided by both data providers.

\subsection{Corporate governance index construction}

We use all 64 individual governance attributes to construct three alternative corporate governance indices. As a first step, we assign a value of one to each governance attribute that a firm has in place and zero otherwise. Our first index, CGI1, is then simply calculated as the percentage of attributes a company has adopted (i.e., attributes which have been assigned a value of one). If a company satisfies all 64 attributes, CGI1 for this company would be equal to 100 . If the company does not provide information on an attribute, we eliminate this attrib- 
ute from the computation of the index. The value of CGI1 can thus be regarded as the percentage of attributes that are not missing and that a company satisfies. This approach is the same as the one used by Aggarwal et al. (2009).

Our second index, CGI2, is built in the same way as CGI1, with the exception that we do not exclude missing attributes from the computation but give each missing attribute a score of 0 , effectively treating it as if the company had not adopted the respective governance attribute (as opposed to simply not disclosing the information whether the attribute is adopted). If the probability that a firm discloses information on a specific governance attribute is positively correlated with the probability that an attribute is adopted, we would expect a stronger valuation effect of CGI2 as compared to CGI1. Both CGI1 and CGI2 are additive indices, a feature common in the literature (see, e.g., Gompers et al., 2003; Bebchuck and Cohen, 2005; Bebchuk et al., 2009). Panel A of Table 3 provides information on the first two governance indices, CGI1 and CGI2. The empirical distributions of CGI1 and CGI2 are displayed in Figure 1. The means (medians) of CGI1 and CGI2 are 61.47 (60.71) and $53.32(50.77)$, respectively, indicating a reasonably symmetric distribution. Figure 1 also reveals that there are substantial differences in corporate governance between the firms in our sample, regardless of which index we use. We thus conclude that our corporate governance proxies are selected and constructed in a way that leads to sufficient variance in the cross-section.

For our third alternative index construction, we follow Larcker et al. (2007) and apply principal component analysis (PCA) to condense the information contained in the governance attributes. There is no well-developed conceptual basis for selecting the relevant corporate governance variables and their relative weights to include in a corporate governance index. PCA allows us to explore the unknown nature of the factor structure that is hidden behind our 
set of individual governance attributes. ${ }^{5}$ Specifically, PCA condenses the information contained in the individual governance attributes into one corporate governance index, or a small number of governance indices (as done in the robustness tests in Section 4.1), by finding the linear combination of the original governance attributes that account for as much variation in the original dataset as possible. Hence, the weighting scheme in our PCA-based index is based on a statistical procedure instead of using equal or arbitrarily chosen weights and aims at "optimally" reflecting the underlying dimension or structure of the individual corporate governance attributes. Larcker et al. (2007) show that such a PCA-based governance index has considerably less measurement error than any individual corporate governance variables or arbitrarily constructed indices. To enhance the interpretability of the PCA results, we use an oblique rotation that allows the principal components to be correlated.

PCA requires the availability of all governance attributes for one specific firm-year observation. As we have an unbalanced panel, we first reduce the number of governance attributes to a number which assures a sufficiently large sample size while including the presumably most important governance attributes. For example, requiring the availability of all variables included in the first sub-category (board accountability) would reduce our sample size to 830 firm-years. Hence, we restrict the governance attributes used in the standard PCA approach to the 17 governance attributes reported in Panel A of Table 4 which we consider to be of high importance and which do not reduce sample size too strongly. We admit that this choice of governance attributes might seem somewhat arbitrary. However, many of the 17 variables have been analyzed as individual corporate governance attributes in prior research, examples being related-party transactions (e.g., Gordon, Henry, and Palia, 2006), board size

\footnotetext{
${ }^{5}$ In the robustness tests of Section 4, we follow Larcker et al. (2007) and construct alternative indices for which PCA not only determines the relative weights of the individual corporate governance attributes but also whether an attribute is included in the index in the first place. We do this by requiring a factor loading in excess of 0.40 in absolute value. Instead of directly using the principal components as governance indices, we then construct governance indices by calculating equally weighted averages of standardized versions of these governance attributes with factor loadings in excess of 0.40 in absolute value.
} 
(Yermack, 1996), equity capital structure (e.g., Gompers, Ishii, and Metrick, 2010), or whether the board is classified (e.g., Faleye, 2007). Moreover, of these 17 attributes, eight coincide with attributes used in Chhaochharia and Laeven (2009) and 12 are included in Aggarwal et al. (2009). The reduction in sample size when using this PCA-based index is 823 firm-years (15.1\%) resulting in 4,630 firm-year observations in the multivariate analyses. ${ }^{6}$ Applying PCA to the 17 governance attributes, we set CGI3 equal to the first principal component (which explains $16.4 \%$ of total variance in the governance attributes). Panel A of Table 3 provides summary statistics for CGI3. ${ }^{7}$

\subsection{Financial data}

We obtain the financial data for the companies included in our sample from Worldscope. We use Tobin's Q as our main performance measure. Following La Porta et al. (2000) and Doidge et al. (2004), we compute Tobin's Q as the sum of total assets less the book value of equity plus the market value of equity, divided by total assets. In the multivariate analysis, we use several control variables. We control for firm size by using the logarithm of total assets (LNTA). Further, and in accordance to prior work investigating the relation between corporate governance and firm value (e.g., see Aggarwal et al., 2009), we control for the past growth in sales over the last two years (PGSALES), the ratio of research and development expenditures to sales (RD/SALES), the ratio of cash to total assets (CASH/ASSETS), the ratio of capital expenditures to assets (CAPEX/ASSETS), the ratio of property-plantsequipment to sales (PPE/SALES), the ratio of earnings before interest and taxes to sales (EBIT/SALES), leverage (LEVERAGE) defined as the ratio of total debt to total assets, a dummy variable whether the firm has American Depository Receipts (ADR) and the percent-

\footnotetext{
${ }^{6}$ In the robustness tests in Section 4.1, we use an extended set of 21 governance attributes for the PCA-based index that additionally includes the following four attributes: dummy variables whether the company has not adopted a shareholder rights plan ("poison pill"), whether the CEO/managing director does not sit on the remuneration committee, whether the remuneration committee is wholly composed of independent board members, and whether the company has separated the chairman and CEO positions. The addition of these four governance attributes, however, reduces the sample size in the multivariate analyses by another 802 observations $(17.3 \%)$.

${ }^{7}$ In the robustness tests of Section 4, we will use various alternative approaches to construct our PCA-based governance indices.
} 
age of shares that are closely held (CLOSELY HELD). All variables are denoted in U.S. dollars. To address the problem of outliers and influential observations, we winsorize the variables PGSALES, PPE/SALES, and EBIT/SALES at the $1 \%$ and the $99 \%$ percentiles and restrict our sample to firm-years with a Tobin's Q of less than or equal to 6 and a LEVERAGE less than or equal to $1 .^{8}$ The summary statistics for Tobin's $\mathrm{Q}$ and all control variables are reported in Panel B of Table 3.

\section{Valuation effect of main corporate governance indices}

In this section, we investigate the valuation effect of our alternative corporate governance indices in a multivariate framework. Specifically, we estimate panel regressions of Tobin's Q on our three alternative governance indices (CGI1, CGI2, and CGI3) and a set of control variables. The choice of control variables is based on Aggarwal et al. (2009). To control for firm size, we include the natural logarithm of total assets (LNTA). The ratio of propertyplants-equipment to sales (PPE/SALES) is included as companies operating with higher (lower) proportions of fixed (intangible) assets may consider it less optimal to adopt a strict corporate governance practice due to less scope to misuse assets. We also control for variables which are usually found to be associated with firm performance: the two-year growth of sales (PGSALES), the ratio of capital expenditures to assets (CAPEX/ASSETS), the ratio of R\&D expenditures to sales (RD/SALES), the ratio of cash to total assets (CASH/ASSETS), the ratio of EBIT to sales (EBIT/SALES), leverage (LEVERAGE), and the percentage of shares that are closely held (CLOSELY HELD). Finally, empirical evidence suggests that companies which are cross-listed on a U.S. exchange are valued higher (Doidge et al., 2004). Hence, we

\footnotetext{
${ }^{8}$ In unreported robustness tests, we find all our results to remain qualitatively unchanged when we omit the winsorization and sample restriction based on the Q- and LEVERAGE-values.
} 
also include a dummy variable whether the firm has American Depositary Receipts outstand$\operatorname{ing}(\mathrm{ADR}) .^{9}$

Columns 1 to 3 in Table 5 report the results for the three governance indices, CGI1, CGI2, and CGI3, respectively. To eliminate a potential omitted variable bias and control for the effect of unobserved variables that are constant over time, we include firm fixed effects. We use Driscoll and Kraay (1998) standard errors, which are heteroskedasticity-consistent and robust to general forms of cross-sectional and temporal dependence. ${ }^{10}$ Most importantly, the coefficients on all three governance indices are estimated positive and significant. Moreover, the coefficient estimates on the governance indices suggest that a one standard deviation increase in CGI1 is associated with an increase in Tobin's Q of 0.06 which amounts to 3.5\% (4.2\%) of mean (median) $\mathrm{Q}$ in our sample. This valuation effect of corporate governance in our sample is comparable to that reported in Chhaochharia and Laeven (2009). The economic magnitude of the valuation effect of CGI3 is somewhat larger (0.08) while the one of CGI2 is substantially larger and amounts to 0.15 or $9 \%(11 \%)$ of mean (median) Q in our sample. Hence, accounting for the fact that companies are more likely to report information on corporate governance attributes they have adopted, an approach that to our knowledge has not been used in prior research, leads to a substantial increase in the estimate of the valuation effect of corporate governance. ${ }^{11}$ Regarding the control variables, our findings largely correspond to those of Aggarwal et al. (2009) with four exceptions. First, the coefficient of RD/SALES is

\footnotetext{
${ }^{9}$ In unreported robustness tests, we include a number of additional control variables including the log of firm age, the percentage of foreign owned shares, and, based on Aggarwal et al. (2009), the ratio of foreign to total sales. The coefficient on age is always estimated positive and often significant while the coefficients on both the percentage of foreign owned shares and the ratio of foreign to total sales are estimated insignificant in all specifications. Moreover, inclusion of the latter two explanatory variables reduces sample size by approximately $10 \%$ and $20 \%$, respectively. Most importantly, the coefficient on corporate governance remains positive and significant in all specifications. Hence, we do not report these extended regressions specifications for space reasons.

${ }^{10}$ Driscoll and Kraay (1998) show that erroneously ignoring cross-sectional dependence in the estimation of linear panel models can lead to severely biased statistical inference. In the context of this study, cross-sectional correlation may arise when the decision to implement a specific corporate governance provision of one particular firm is related to or coincides with the decisions of other firms. Alternatively, we also perform the estimations with cluster-robust standard errors and find the results to remain qualitatively unchanged.

${ }^{11}$ We further analyze the economic effect of corporate governance on firm value in Section 4.5.
} 
not significant in all three specifications. However, if we follow Aggarwal et al. (2009) and include industry fixed effects (as we do in Columns 4 to 6), the coefficient of RD/SALES turns positive and significant as well. Second, consistent with Aggarwal et al. (2009), the coefficients of PPE/SALES are negative. However, in Table 5 they are all significant at the $1 \%$ while being insignificant in Aggarwal et al. (2009). Third, the coefficient on LEVERAGE is in some specifications significantly negative whereas the estimations of Aggarwal et al. (2009) never show significant coefficients for LEVERAGE. Fourth, the coefficient on CLOSELY HELD is negative and significant in all three specifications. This finding contrasts with Aggarwal et al. (2009) and earlier literature (e.g., La Porta et al., 1999; Stulz, 2005) and might be due to the relatively high mean $(24 \%)$ and median $(28 \%)$ values of closely held shares in our sample. ${ }^{12}$ In their seminal paper, Morck et al. (1988) report a negative relationship between share ownership of the board of directors and firm value in the $5 \%$ to $25 \%$ ownership range and attribute these findings to a domination of the incentive alignment effect by the entrenchment effect. A similar effect might be at work for block ownership more generally in our sample.

Variations across countries have been shown to matter a lot for corporate governance (see, e.g., Doidge et al., 2007). We aim to account for this fact in two ways. First, in Columns 4 to 6 of Table 5, we control for country-specific instead of firm-specific unobservable heteroskedasticity. In addition, we include industry and year fixed effects. Second, in Columns 7 and 8, we follow Chhaochharia and Laeven (2009) and adjust the CGI scores by subtracting the number of governance attributes that every firm of a country fulfills in a given year from the number of attributes a firm has in place. Doing so enables us to focus on changes in the governance scores which are truly firm-specific and not influenced by country-specific differences in legal regimes. For the PCA-based CGI3, such an adjustment is not possible. The re-

\footnotetext{
${ }^{12}$ Unfortunately, Aggarwal et al. (2009) do not report descriptive statistics for closely held shares and therefore we cannot compare the distribution of the variable between the two samples.
} 
sults in Columns 4 to 8 show that these alternative specifications leave the results of Columns 1 to 3 qualitatively unchanged. Most importantly, the coefficients on the governance indices all remain positive and significant. The only notable change in the control variables is that the coefficient on RD/SALES turns positive and significant when country dummy variables are included (Columns 4 to 6$)$.

\section{Robustness Tests and Extensions}

\subsection{Robustness of main results}

One possible concern about the results reported in the previous section is that they could be driven by one single year or one single country. In our first set of robustness tests, we thus analyze our sample on a year-by-year basis and for the five countries with the most firm-year observations. The results are reported in Table 6 and show that the positive effect of corporate governance on firm value in general remains significant both over time and if we restrict our sample to specific countries. The two exceptions are the analysis for 2003 (Column 1) and Japan (Column 6). The insignificant coefficient on CGI1 in Column 1 might be related to the relatively small sample size as compared to the four subsequent years. As for Japan, Japanese corporate governance is well-known to differ from that in other countries (e.g., Berglöf and Perotti, 1994; La Porta et al., 2000; Claessens et al., 2002). Hence, it is not surprising that our results show no relation between our governance indices and firm value in Japan. ${ }^{13}$ To save space, we only report the results for regressions including CGI1. However, all results reported in Table 6 remain qualitatively unchanged when CGI1 is replaced by CGI2 or CGI3. For Canada, we exclude the control variable CASH/ASSETS since Worldscope's coverage of this

\footnotetext{
${ }^{13}$ In Japan keiretsu membership seems to be the most important corporate governance attribute while others such as for example ownership structure are of less, if of any, importance. Lins and Servaes (1999), for example, find that a strong keiretsu membership is an indicator of corporate governance problems while ownership structure is not. Claessens et al. (2002) exclude Japan from their analysis of ownership structure in East Asia because the keiretsu system affects governance in ways that cannot be captured by ownership variables.
} 
variable for Canadian firms is very poor, leading to a reduction in the sample size by about $60 \%$.

In Table 7, we report the results of our next robustness test, where we use a number of alternative approaches to construct our PCA-based governance indices. In the first approach (Column 1), we use the same 17 governance attributes as before but retain the first five components, which jointly explain $51.3 \%$ of total variance in the original governance attributes. That is, we have five governance indices in the specific regression equation. In the second approach (Columns 2 and 3), used to enhance the interpretability of the results and to check for their robustness, we use a similar approach as Larcker et al. (2007) and associate with each component those governance attributes that have a factor loading in excess of 0.40 in absolute value. Instead of directly using the principal components as governance indices, we then follow Larcker et al. (2007) and construct governance indices ("construct scores") by calculating equally weighted averages of standardized versions of the governance attributes with factor loadings in excess of 0.40 in absolute value. Since these alternative governance indices are weighted averages of standardized variables, their mean is equal to zero and the variance equal to one. Panel B of Table 4 reports the expected sign of the correlation between the principal components and firm value and the percentage of variance explained by each component and cumulatively. The expected sign is derived from the signs and magnitudes of the factor loadings of the individual governance attributes in each component. For the governance indices directly based on the first five principal components, we sum all factor loadings over the 17 governance attributes and attribute a positive expectation for the principal components with a value larger than one (the sums of factor loadings for the five components are $0.24,2.06,1.96,0.30$, and 1.09 , respectively). For the governance indices based on the equally weighted averages of the standardized attributes, we derive the sign of the expected correlation from whether the sum of factor loadings in excess of 0.40 in absolute terms is larger than 
zero (larger than 0.5 ), smaller than zero (smaller than -0.5 ), or close to zero (between -0.5 and 0.5). However, as the importance of the individual attributes may differ substantially, lower sums of the factor loadings might nevertheless be associated with higher positive coefficients than higher sums with relatively less weights attributed to the most important governance attributes. The factor loadings for the first five principal components are reported in Panel A of Table 4.

The third (Columns 4 and 5) and fourth (Columns 6 and 7) alternative approaches are identical to the first two approaches but are based on a larger set of 21 governance attributes. This set additionally includes dummy variables whether the company has not adopted a shareholder rights plan ("poison pill"), whether the $\mathrm{CEO} /$ managing director does not sit on the remuneration committee, whether the remuneration committee is wholly composed of independent board members, and whether the company has separated the chairman and CEO positions. Three of these four potentially important governance attributes are included in Chhaochharia and Laeven (2009) and two in Aggarwal et al. (2009). The addition of these four governance attributes, however, reduces the sample size in the multivariate analyses by 802 observations $(17.3 \%)$ when directly using the principal components as governance indices. In contrast, when using the equally weighted average of the standardized versions of the governance attributes, which exhibit factor loadings in excess of 0.40 in absolute value, in the first five principal components as governance indices the sample size remains unchanged.

Overall, the results of these different variants of our PCA-based corporate governance indices in Table 7 show that the positive and significant effect of corporate governance on firm value is robust to the alternative specifications of the PCA-based governance indices - at least for the governance indices based on the first, second, and fourth principal components. 


\subsection{Corporate social responsibility}

Using GMI's dataset on governance variables enables us to investigate the value of corporate behavior attributes such as for example whether the company discloses its policy regarding corporate level political donations or whether the company has been charged with workplace safety violations. Such "soft" factors, often termed "corporate social responsibility (CSR)", have not yet been included in the previous literature on corporate governance and firm value with very few exceptions. There exists some research on some specific aspects of CSR such as corporate tax avoidance (e.g., Desai and Dharmapala, 2009). The majority of prior research on the relation between CSR and financial performance, however, use a measure of environmental performance as their measure of CSR. Konar and Cohen (2001), for example, examine the extent to which a firm's environmental reputation is valued by investors. They find that, after controlling for other variables known to affect the market value of a firm, bad environmental performance is negatively correlated with the intangible asset value of S\&P 500 firms. Consistently, Dowell et al. (2000) find that U.S.-based multinational enterprises adopting a single, stringent global environmental standard have much higher market values than firms defaulting to less stringent, or poorly enforced host country standards. ${ }^{14}$ Another problem of prior research, besides using a very narrow definition of CSR, is that these studies do not account for standard corporate governance attributes when investigating the valuation effect of corporate governance.

The only three exceptions we are aware of, and the research closest to ours, are Fisman, Heal, and Nair (2006), Harjoto and Jo (2008), and Barnea and Rubin (2010). Fisman, Heal, and Nair (2006) use data on CSR from the Kinder, Lydenberg, and Domini's (KLD) Socrates database and find in general a negative relation between CSR and firm value. However, they show that the presence of outside blockholders with board representation and a stronger com-

\footnotetext{
${ }^{14}$ Consistent with these findings, Kempf and Osthoff (2007) show in a recent paper that buying stocks of companies with good social behavior and selling stocks of social underperformers generates an abnormal return of $8.7 \%$ per year.
} 
petition on the product markets both lead to a more positive relationship between CSR and profitability. Harjoto and Jo (2008) use corporate governance data from IRRC / RiskMetrics and CSR data from the KLD Socrates database to obtain a panel dataset from 1993 to 2004. Most importantly, they show that CSR is positively associated with corporate governance and that both corporate governance and CSR have a positive valuation effect. They argue that firms use corporate governance mechanisms along with CSR to reduce the conflicts-ofinterest between shareholders and non-investing stakeholders. Barnea and Rubin (2010) argue that a firm's managers and large blockholders may seek to over-invest in CSR for their private benefit to the extent that doing so improves their reputation as good global citizens. Using CSR data also from the KLD Socrates database, they find that managers' ownership is negatively related to the firms' CSR, while institutional ownership is uncorrelated with it. Hence, they conclude that insiders induce firms to over-invest in CSR when they bear little of the cost of doing so. A common problem in all these studies is that the measure of CSR is binary and only indicates whether a firm invests in CSR or not. Moreover, while Harjoto and Jo (2008) account for the endogeneity of CSR but not corporate governance, the other two studies do not account for a potential endogeneity of both CSR and corporate governance.

To investigate the value impact of CSR, we first aggregate the nine variables pertaining to GMI's corporate behavior category to an index. Similar as for the corporate governance index, we construct three different indices. The first index, entitled CSRI, is constructed in the same way as CGI2, namely by dividing the number of attributes a company has adopted by the total number of CSR attributes. This index construction treats missing attributes as if these attributes were not adopted. The second index, CSRI_PCA, is constructed in the same way as CGI3 by employing principal component analysis and using the first principal component as the governance index. The third index, CSRI_ADJ is equal to CSRI but adjusted according to 
Chhaochharia and Laeven (2009) by subtracting the number of governance attributes that every company in a given country fulfills in a given year.

Before investigating the valuation effect of CSR, we investigate the relation between corporate governance and CSR. Harjoto and Jo (2008) find that CSR is positively associated with corporate governance while Barnea and Rubin (2010) find a negative relation (when governance is measured by managerial ownership). In our sample, the correlations between the three alternative CSR indices and corporate governance are all positive and significant at the $1 \%$ level $(0.36,0.12$, and 0.29$)$. As various firm characteristics may be related to both corporate governance and CSR, we also estimate similar regressions of our CSR indices on corporate governance and a set of control variables as in Harjoto and Jo (2008). Independent of the set of control variables and the type of fixed effects we include, the coefficient on corporate governance is always estimated positive and significant at the $1 \%$ level. Hence, our results are rather consistent with Harjoto and Jo (2008) than with Barnea and Rubin (2010) who only use ownership as a measure of corporate governance. Moreover, we find that larger and more profitable firms and firms with ADRs have higher CSR index values. The coefficients on all other variables are not consistently significant across the alternative specifications we tested (the results are not reported for space reasons).

To investigate the possible relation between CSR and firm value, we re-estimate the main regression specification of Table 5 and replace the original governance indices by the CSR indices. To eliminate potentially spurious regression results by simply picking up the effect of corporate governance, we control for the "standard" corporate governance attributes by including the additional control variable CGI_CONTR, which is an auxiliary governance index constructed in the same way as CGI2 but excluding the nine CSR attributes. The results are reported in Columns 1 to 3 of Table 8 and show a significant and robust positive effect of good corporate behavior on firm value for all three alternative CSR indices. Moreover, the 
relation between the governance control index, CGI_CONTR, and firm value remains positive and highly significant. In Columns 4 and 5, we replace the firm fixed effects by industry, country, and year fixed effects and find the results to remain virtually unchanged.

CSR may be less profit-motivated in companies with poor corporate governance as ineffective monitoring and control mechanisms may allow the board and management to make CSR expenditures according to their personal preferences rather than profit concerns (e.g., Fisman, Heal, and Nair, 2006; Harjoto and Jo, 2008). Hence, in Columns 6 and 7, we additionally include interaction terms between CSRI and CGI_CONTR and between CSRI_PCA and CSRI_CONTR, respectively. If a good corporate governance in fact assures that CSR expenditures are profit-oriented rather than serving the managers' personal ambitions, for example to improve their reputations as good global citizens, we would expect a positive and significant coefficient on the interaction term. In fact, the coefficient on the interaction term is positive and significant at the $1 \%$ and $5 \%$ level in Columns 6 and 7 , respectively, while the coefficient on CSR turns insignificant in both specifications. Hence, the positive valuation effect of CSR only applies to firms with a good corporate governance structure.

\subsection{Endogeneity}

Endogeneity is a crucial issue in investigating the effects of corporate governance on firm value. Recent papers additionally argue that such endogenous relations may be dynamic (e.g., Wintoki et al., 2008). Hermalin and Weisbach (2004) and Wintoki et al. (2008) argue that current actions of a firm affect future corporate governance as well as performance, which will in turn affect the firms' future actions.

To control for such a dynamic endogeneity, unobservable heterogeneity, and simultaneity, we follow Wintoki et al. (2008) and use the dynamic panel GMM estimator as proposed by Arellano and Bover (1995) and Blundell and Bond (1998). The estimation consists of the 
following three steps: First, we rewrite the regression equation as a dynamic model that includes lagged performance as an explanatory variable. Second, we first difference all variables. This controls for unobserved heterogeneity and eliminates a potential omitted variables bias. Third, we estimate the model by GMM and use lagged values of the governance indices and performance as instruments. Using lagged variables as instruments for the present values of these variables controls for potential simultaneity and reverse causality. In addition, this estimation procedure allows all the explanatory variables (i.e., the governance indices and all control variables) to be treated as endogenous. ${ }^{15}$

The results for the three alternative corporate governance indices are reported in the first three columns of Table 9. They indicate that the coefficients on all three alternative governance indices remain positive and statistically significant at the $10 \%$ level or better. These results alleviate endogeneity concerns and provide evidence of a causal link between our corporate governance indices and firm value.

The same endogeneity concerns also apply to CSR. Specifically, firms that have performed better in the past can possibly afford to act more socially responsible. Hence, in a next step, we extend our dynamic panel GMM regressions to include CSR as an additional endogenous variable. The results for the two alternative CSR indices, CSRI and CSRI_PCA, are reported in Columns 4 and 5 of Table 9. Again we find the coefficients on both CSR indices as well as on the corporate governance indices to remain positive and statistically significant at the $10 \%$ level or better indicating a causal link between corporate governance and firm value and between CSR and firm value.

\footnotetext{
${ }^{15}$ Many papers in the literature use instrumental variables. However, instrumental variables approaches are problematic because of a lack of suitable instruments for corporate governance (e.g., Larcker et al., 2007). An approach recently used by Aggrawal et al. (2009) to circumvent the problem of identifying valid instruments is to replace firm-level governance by the average governance index value of all firms in the same country, industry, and year. When applied to our sample, we find our results to remain qualitatively unchanged and therefore do not report them in a table.
} 
Finally, we follow Harjoto and Jo (2008) and estimate Heckman (1979) selection model regressions to account for a potential endogeneity of CSR. In contrast to the GMM approach, this analysis neglects the endogeneity of corporate governance and other variables. In a first step, we redefine CSRI and CSRI_PCA into dummy variables that equal one for firm-years for which the value of CSRI (CSRI_PCA) is larger than the median value. ${ }^{16}$ These dummy variables are the dependent variables of the first-stage probit regressions. The explanatory variables in the first stage regressions are based on Harjoto and Jo (2008) and include CGI_CONTR, LNTA, RD/SALES, EBIT/SALES, LEVERAGE, and industry dummy variables. ${ }^{17} \mathrm{We}$ do not report the results in a table for space reasons. Most importantly, the coefficients on corporate governance, firm size, and profitability (EBIT/SALES) are estimated positive and significant in all specifications. The dependent variable of the second-stage regressions is Tobin's Q and we include the same set of explanatory variables as in the GMM regressions reported in Columns 4 and 5. LAMBDA is the self-selection parameter (or inverse Mill's ratio) from the first-stage probit regressions. The results are reported in the last two columns of Table 9. Again, we find positive and significant coefficients on both CSR indices as well as on the corporate governance control indices. The coefficient on LAMBDA is significant in both regressions indicating that firm characteristics that make firms choose to spend more on CSR are significantly correlated with firm value.

\subsection{Individual governance attributes}

So far, we have focused on governance indices and their value impact. However, academic studies, the regulatory bodies, and the press at large generally pay more attention to individual governance attributes than to an aggregate of attributes. In addition, it is potentially

\footnotetext{
${ }^{16}$ In unreported robustness tests, we alternatively use dummy variables for whether CSRI or CSRI_PCA are in in top $25 \%$ percentile of the distribution. The results are virtually unchanged and therefore not reported for space reasons.

${ }^{17}$ In unreported robustness tests, we use a number of additional control variables including past sales growth (PGSALES), the ratio of cash to total assets (CASH/ASSETS), the ratio of capital expenditures to assets (CAPEX/ASSETS), the ratio of property-plants-equipments to sales (PPE/SALES), a dummy variable whether the firm has ADRs (ADR), and the percenatge of closely held shares (CLOSELY HELD). The results of the second-stage regressions remain qualitatively unchanged.
} 
interesting and revealing to learn which specific attributes are significantly related to firm value and thereby contribute to the positive valuation effect of the governance indices. Hence, in this section, we investigate the relation between two different subsets of individual governance attributes and firm value. First, we include the 17 variables contained in our main PCAbased governance index, CGI3. The second subset consists of our nine CSR attributes. Panel A of Table 10 lists the 17 individual governance attributes, Panel B of Table 10 the nine CSR attributes. We investigate the valuation effect of the individual corporate governance and CSR attributes based on similar fixed effects regressions as reported in Column 1 of Table 5. In Column 1 of Table 10, we include each governance / CSR attribute separately - along with the set of control variables. In Column 2, we additionally include the remaining 16 (9) individual governance attributes as control variables. In Panel B, we also include CGI_CONTR to control for the effect of corporate governance on firm value.

The results in Panel A show that some of the included attributes have a significantly positive effect on firm value, regardless of whether they are included individually in the regression or whether they are included jointly with the other 16 attributes. Most importantly, board size, a dummy variable whether a company has received a qualified audit opinion, a dummy variable whether a company has a one-share-one-vote policy, a dummy variable whether shareholders have the right to convene an EGM, and a dummy variable whether the audit committee is wholly composed of independent members are all positive and significant at the $5 \%$ level or better. In contrast, not requiring a supermajority to approve a merger has a negative effect on firm value. Many of these results confirm earlier findings in the literature, for example on board size (e.g., Yermack, 1996) and audit committee composition (Chan and $\mathrm{Li}, 2008)$.

In Panel B of Table 10, we find that four CSR attributes have a positive effect on firm value, regardless of whether they are included individually in the regression or whether they 
are regressed jointly along with the other eight attributes. These attributes include dummy variables whether the company discloses its workplace safety record, if regulatory investigation for a material issue other than accounting irregularities is under way, if the company discloses its policy regarding corporate level political donations, and if the company has not been charged with workplace safety violations. These results provide further validation of our finding that governance attributes describing certain behavioral aspects of a company have a strong positive effect on firm value even when standard governance attributes are accounted for, a relationship that has not been investigated or documented in the literature to date.

\subsection{The economic importance of corporate governance}

In this last section of the paper, we investigate the economic importance of the valuation effect of corporate governance. As the majority of previous research focuses on the statistical significance of the governance coefficient, academic research provides little insight into the economic significance of the effect of corporate governance on firm value. Hence, in a first step, we provide an overview of the economic effect of corporate governance on firm value as estimated in seven recent, and mostly well-known and often-cited academic studies in the area. To be included in our survey, the studies have to use Tobin's Q as a measure of firm value / performance, use a comprehensive corporate governance index and not individual corporate governance attributes, and include either the U.S. or several non-U.S. countries in the sample. Moreover, the paper has to provide an estimate of the standard deviation of the corporate governance index for that the economic effect can be estimated. ${ }^{18}$ In a second step, we investigate differences in the economic effect that result from changes in the index construction and alternative econometric estimation techniques based on our international sample using governance data from GMI.

\footnotetext{
${ }^{18}$ Examples of studies we considered, but which could not be included for one or another reason are Doidge et al. (2007) and Larcker et al. (2007) as both studies do not investigate the valuation effect of governance. Bebchuck et al. (2009) had to be excluded as the standard deviation of the governance index is not reported. Cremers and Nair (2005) and Bruno and Claessens (2010) do not estimate standard Q-regressions that allow to infer the economic effect of firm-level corporate governance.
} 
A survey of the seven papers is provided in Table 11. Most importantly, the economic effect varies widely between the different studies and sometimes also within the studies, in particular in studies that additionally attempt to control for endogeneity (e.g., Chhaochharia and Laeven, 2009). ${ }^{19}$ The smallest effect found in these studies is in Cremers and Ferrell (2010), who find an increase in the G-index to be associated with a decrease in Q of approximately 0.033 , or $2 \%$ of mean Q in their U.S. sample covering nearly 30 years. The largest effect of 0.421 (22\% of mean Q) is found by Durnev and Kim (2005) when they account for endogeneity concerns by estimating a system of simultaneous equations with three-stage least squares. The average of the OLS-based estimates in the seven surveyed papers is an increase in $\mathrm{Q}$ of 0.13 when the governance index increases (decreases in the case of the G-index) by one standard deviation. If we only consider developed countries, as we do in this study, the effect drops to 0.09 . For developing countries, the economic effect is substantially larger (0.25). This finding is not surprising given the evidence in Klapper and Love (2004) and Durnev and Kim (2005) both documenting a stronger effect of corporate governance on firm value in less investor-friendly countries.

To assess the economic effect of corporate governance on firm value in this study, we start with the first three columns of Table 5. The coefficient estimate on CGI1 shows that a one standard deviation increase in CGI1 is associated with an increase in Q of $0.06(0.005 *$ 11.12) which amounts to $3.5 \%(4.2 \%)$ of mean (median) $\mathrm{Q}$. This finding is similar to but somewhat lower than those in Aggarwal et al. (2009) and Chhaochharia and Laeven (2009) which are the studies most comparable to ours. A one standard deviation increase in CGI2 and CGI3 are associated with an increase in Q of 0.15 and 0.08 , respectively. Hence, in particular the economic effect of CGI2 on Q is substantially larger, confirming the conjecture, stated in Section 2.2, that the probability that a firm discloses information on a specific governance at-

\footnotetext{
${ }^{19}$ For simplicity, we do not report all different estimates reported in a study but only those of the main regression specification of the paper. We report two values if there is a major change in the setup within a paper (e.g., Chhaochharia and Laeven, 2009).
} 
tribute is positively correlated with the probability that an attribute is adopted. Columns 4 to 6 show that using country, industry, and year instead of firm fixed effects leaves the magnitude of the valuation effect virtually unchanged. In contrast, when we adjust the CGI scores by subtracting the number of governance attributes that every firm of a country fulfills in a given year from the number of attributes a firm has in place, the economic effect increases substantially. Specifically, a one standard deviation increase in such an adjusted version of CGI1 and CGI2 is associated with an increase in $\mathrm{Q}$ of 0.14 and 0.28 , respectively. As this alternative index construction enables us to focus on changes in the governance scores which are truly firm-specific and not influenced by country-specific differences in legal regimes, we would in fact expect a lager economic effect of these indices.

Table 11 shows that alternative estimation techniques may strongly affect the estimate of the economic size of the valuation effect of governance. In particular, methods that account for the endogeneity of corporate governance (and possibly other variables) seem to boost the economic significance of the valuation effect (e.g., Durnev and Kim, 2005; Chhaochharia and Laeven, 2009). ${ }^{20}$ When looking at the GMM results in Table 9, we find little differences in the economic effect of corporate governance on Q as compared to the OLS specifications in Table 5. ${ }^{21} \mathrm{~A}$ one standard deviation increase in CGI1, CGI2, and CGI3 is associated with an increase in $\mathrm{Q}$ of $0.08,0.10$, and 0.08 . Hence, the differences resulting from the alternative approaches to construct the indices are somewhat reduced but the effect of CGI2 remains larger than the effect of CGI1 and CGI3.

To summarize, our results in Sections 3 and 4 indicate that the statistical significance of the valuation effect of corporate governance is virtually unaffected by both the construction of

\footnotetext{
${ }^{20}$ Beiner et al. (2006) and Black et al. (2006) show that instrumental variables approaches may lead to an overestimate of the valuation effect of corporate governance.

${ }^{21}$ One reason might be that we have a longer panel and therefore more lags (and consequently better instruments) and less problems with sample size when using lagged variables as instruments as compared to Chhaochharia and Laeven (2009), for example.
} 
the index and the choice of the estimation methodology. In this sub-section, however, we show that the economic significance of this valuation effect strongly depends on how the index is constructed. In particular, when we account for the fact that companies are more likely to report information on corporate governance attributes they have adopted or focus on changes in the governance scores which are truly firm-specific and not influenced by countryspecific differences in legal regimes, the economic importance of the valuation effect substantially increases.

\section{Conclusions}

In this paper, we investigate the effect of firm-level corporate governance on firm value using a previously unused dataset by Governance Metrics International (GMI) which covers 64 individual corporate governance attributes on over 2,300 firms from 22 developed countries over a five-year time period from 2003 to 2007 . We aggregate the 64 governance attributes to governance indices using different techniques. First, based on related previous work (e.g., Aggarwal et al., 2009), we construct additive indices. Second, we use principal component analysis (PCA) to extract governance indices from the 64 attributes. Moreover, we specifically investigate whether governance attributes that reflect a company's social behavior also affect firm value.

We find a strong and positive relation between firm-level corporate governance and firm valuation and between a company's social behavior and firm value. These results are robust to the different techniques used to construct the corporate governance indices, a breakdown of the sample by both calendar year and country, and a dynamic panel GMM estimator.

Our results indicate that better corporate governance practices are reflected in statistically and economically significantly higher market values. Hence, at least for the average firm in our sample, the costs of the implementation of the corporate governance mechanisms seem to 
be smaller than the monitoring benefits, resulting in higher cash flows accruing to investors and lower costs of capital for the firms. Consequently, from the companies' perspective, corporate governance should be understood as an opportunity rather than an obligation and pure cost factor. 


\section{References}

Aggarwal, R., Williamson, R., 2006. Did new regulations target the relevant corporate governance attributes? Working Paper, Georgetown University.

Aggarwal, R., Erel, I., Stulz, R., Williamson, R., 2009. Differences in governance practice between U.S. and foreign firms: measurement, causes, and consequences. Review of Financial Studies 22, 3131-3169.

Arellano, M., Bover, O., 1995. Another look at the instrumental variable estimation of errorcomponent models. Journal of Econometrics 68, 29-51.

Balasubramaniam, B.N., Black, B.S., Khanna, V.S., 2009. Firm-level corporate governance in emerging markets: A case study of India. ECGI Working Paper \#119.

Barnea, A., Rubin, A., 2010. Corporate social responsibility as a conflict between shareholders. Journal of Business Ethics 97, 71-86.

Bebchuk, L., Cohen, A., 2005. The costs of entrenched boards. Journal of Financial Economics $78,409-433$.

Bebchuk, L., Cohen, A., Ferrell, A., 2009. What matters in corporate governance? Review of Financial Studies 22, 783-827.

Beiner, S., Drobetz, W., Schmid, M.M., Zimmermann, H., 2006. An integrated framework of corporate governance and firm valuation. European Financial Management 12, 249-283.

Berglöf, E., Perotti, E., 1994. The governance structure of the Japanese financial keiretsu. Journal of Financial Economics 36, 259-284.

Black, B.S., Kim, W., Jang, H., 2006. Does corporate governance affect firms' market values? Evidence from Korea. Journal of Law, Economics and Organization 22, 366-413.

Blundell, R., Bond, S., 1998. Initial conditions and moment restrictions in dynamic panel data models. Journal of Econometrics 87, 115-143.

Brown, L., Caylor, M., 2006. Corporate governance and firm valuation. Journal of Accounting and Public Policy 25, 409-434.

Bruno, V., Claessens, S., 2010. Corporate governance and regulation: can there be too much of a good thing? Journal of Financial Intermediation 19, 461-482. 
Chan, K. C., Li, J., 2008. Audit committee and firm value: Evidence on outside top executive as expert-independent directors. Corporate Governance: An International Review 16, 16-31.

Chhaochharia, V., Grinstein, Y., 2007. Corporate governance and firm value: The impact of the 2002 governance rules. Journal of Finance 62, 1789-1825.

Chhaochharia, V., Laeven, L., 2009. Corporate governance norms and practices. Journal of Financial Intermediation 18, 405-431.

Claessens, S., Djankov, S., Fan, J.P.H., Lang, L.H.P., 2002. Disentangling the incentive and entrenchment effects of large shareholders. Journal of Finance 57, 2741-2771.

Coles, J., Lemmon, M., Meschke, J.F., 2007. Structural models and endogeneity in corporate finance: The link between managerial ownership and corporate performance. Working Paper, University of Utah.

Core, J., Guay, W.R., Rusticus, T.O., 2006. Does weak governance cause weak stock returns? An examination of firm operating performance and investors' expectations. Journal of Finance $61,655-687$.

Cremers, M., Ferrell, A., 2010. Thirty years of governance governance: Firm valuation and stock returns. Working Paper, Yale School of Management.

Cremers, M., Nair, V.B., 2005. Governance mechanisms and equity prices. Journal of Finance 60, 2859-2894.

Desai, M., Dharmapala, D., 2009. Corporate tax avoidance and firm value. Review of Economics and Statistics 91, 537-546.

Doidge, C., Karolyi, G., Stulz, R., 2004. Why foreign firms that list in the U.S. are worth more? Journal of Financial Economics 71, 205-238.

Doidge, C., Karolyi, G., Stulz, R., 2007. Why do countries matter so much for corporate governance? Journal of Financial Economics 86, 1-39.

Dowell, G., Hart, S., Yeung, B., 2000. Do corporate global environmental standards create or destroy market value? Management Science 46, 1059-1074.

Driscoll, J.C., Kraay, A.C., 1998. Consistent covariance matrix estimation with spatially dependent panel data. Review of Economics and Statistics 80, 549-560. 
Drobetz, W., Schillhofer, A., Zimmermann, H., 2004. Corporate governance and expected stock returns: evidence from Germany. European Financial Management 10, 267-93.

Durnev, A., Kim, E.H., 2005. To steal or not to steal: firm attributes, legal environment and valuation. Journal of Finance 60, 1461-1493.

Ertugrul, M., Hegde, S., 2009. Corporate governance ratings and firm performance. Financial Management 38, 139-160.

Faleye, O., 2007. Classified boards, firm value, and managerial entrenchment. Journal of Financial Economics 83, 501-529.

Fisman, R., Heal, G., Nair, V., 2006. Corporate social responsibility: Doing well by doing good? Working Paper, Columbia University.

Francis, J., Khurana, I., Pereira, R., 2005. Disclosure incentives and effects on cost of capital around the world. The Accounting Review 80, 1125-1162.

Gillan, S., Hartzell, J., Starks, L., 2003. Explaining corporate governance: Boards, bylaws, and charter provisions. Working Paper, University of Texas at Austin.

Gompers, P.A., Ishii, J., Metrick, A., 2003. Corporate governance and equity prices. Quarterly Journal of Economics 118, 107-155.

Gompers, P.A., Ishii, J., Metrick, A., 2010. Extreme governance: An analysis of dual-class firms in the United States. Review of Financial Studies 23, 1051-1088.

Gordon, E.A., Henry, E., Palia, D., 2006. Related party transactions: Associations with corporate governance and firm value. Working Paper, Rutgers University.

Harjoto, M.A., Jo, H., 2008. Why do firms engage in corporate social responsibility? Working Paper, Santa Clara University.

Heckman, J.J., 1979. Sample selection bias as a specification error. Econometrica 47, 153-161. Hermalin, B.E., Weisbach, M.S., 2004. Boards of directors as an endogenously determined institution: A survey of the economic literature. Federal Reserve Bank of New York Economic Policy Review 9, 7-26.

Jensen, M.C., Meckling, W.H., 1976. Theory of the firm: Managerial behavior, agency costs and ownership structure. Journal of Financial Economics 3, 305-360. 
Kempf, A., Osthoff, P., 2007. The effect of socially responsible investing on portfolio performance. European Financial Management 13, 908-922.

Khanna, T., Kogan, J., Palepu, K., 2006. Globalization and similarities in corporate governance: A cross country analysis. Review of Economics and Statistics 88, 69-90.

Klapper, L., Love, I., 2004. Corporate governance, investor protection and performance in emerging markets. Journal of Corporate Finance 10, 703-728.

Konar, S., Cohen, M.A., 2001. Does the market value environmental performance? Review of Economics and Statistics 83, 281-289.

La Porta, R., Lopez-de-Silanes, F., Shleifer, A., Vishny, R., 1998. Law and finance. Journal of Political Economy 106, 1113-1155.

La Porta, R., Lopez-De-Silanes, F., Shleifer, A., 1999. Corporate ownership around the world. Journal of Finance 54, 471-517.

La Porta, R., Lopez-de-Silanes, F., Shleifer, A., Vishny, R.W., 2000. Investor protection and corporate governance. Journal of Financial Economics 58, 3-29.

La Porta, R., Lopez-de-Silanes, F., Shleifer, A., Vishny, R., 2002. Investor protection and corporate valuation. Journal of Finance 57, 1147-1170.

Larcker, D., Richardson, S., Tuna, I., 2007. Corporate governance, accounting outcomes and organizational performance. The Accounting Review 82, 963-1008.

Lins, K., Servaes, H., 1999. International evidence on the value of corporate diversification. Journal of Finance 54, 2215-2239.

Morck, R., Shleifer, A., Vishny, R., 1988. Management ownership and market valuation: An empirical analysis. Journal of Financial Economics 20, 293-316.

Shleifer, A., Vishny, R., 1997. A survey of corporate governance. Journal of Finance 52, 737783.

Stulz, R., 2005. The limits of financial globalization. Journal of Finance 60, 1595-1638.

Wintoki, M.B., Linck, J.S., Netter, J.M., 2008. Endogeneity and the dynamics of corporate governance. Working Paper, University of Kansas School of Business.

Yermack, D., 1996. Higher market valuation for firms with a small board of directors. Journal of Financial Economics 40, 185-211. 
Table 1: Overview of countries included in the sample

\begin{tabular}{lrr}
\hline Country & Observations & o of sample \\
\hline Australia & 419 & $6.29 \%$ \\
Austria & 56 & $0.84 \%$ \\
Belgium & 90 & $1.35 \%$ \\
Canada & 471 & $7.07 \%$ \\
Denmark & 80 & $1.20 \%$ \\
Finland & 92 & $1.38 \%$ \\
France & 344 & $5.16 \%$ \\
Germany & 337 & $5.06 \%$ \\
Greece & 88 & $1.32 \%$ \\
Hong Kong & 203 & $3.05 \%$ \\
Ireland & 61 & $0.92 \%$ \\
Italy & 201 & $3.02 \%$ \\
Japan & 1,762 & $26.44 \%$ \\
Netherlands & 147 & $2.21 \%$ \\
New Zealand & 45 & $0.68 \%$ \\
Norway & 57 & $0.86 \%$ \\
Portugal & 45 & $0.68 \%$ \\
Singapore & 208 & $3.12 \%$ \\
Spain & 173 & $2.60 \%$ \\
Sweden & 194 & $2.91 \%$ \\
Switzerland & 183 & $2.75 \%$ \\
UK & 1,407 & $21.12 \%$ \\
\hline Total & 6,663 & $100 \%$ \\
\hline
\end{tabular}

The table reports the number of observations (Observations) and the percentage each country accounts for in the full sample (\% of sample) for each country covered in the study. The total sample consists of 6,663 firm years. We drop countries for which we have less than 10 firm-year observations (i.e., Argentina, Colombia, Czech Republic, Egypt, Hungary, Iceland, Israel, Jordan, Morocco, Pakistan, Peru, Philippines, Thailand, and Venezuela) and emerging and developing countries (i.e., Brazil, Chile, China, India, Indonesia, Malaysia, Mexico, Russia, South Africa, South Korea, Taiwan, and Turkey). 
Table 2: Firms meeting requirements for governance attributes

\begin{tabular}{|c|c|}
\hline Individual governance attribute & $\begin{array}{c}\% \text { of firms meeting } \\
\text { attributes }\end{array}$ \\
\hline \multicolumn{2}{|l|}{ Board Accountability } \\
\hline 1. Board members are subject to annual election by all shareholders & $22.2 \%$ \\
\hline 2. Non-executive board members have a formal session without executives once a year & $55.3 \%$ \\
\hline 3. Board performance is periodically evaluated & $86.2 \%$ \\
\hline 4. Company discloses a code of ethics for senior executives & $45.3 \%$ \\
\hline 5. Company discloses its corporate governance policies or guidelines & $64.2 \%$ \\
\hline 6. Board or a committee is responsible for CEO succession planning & $82.8 \%$ \\
\hline 7. Company has not failed to adopt the recommendations of a shareholder proposal & $99.8 \%$ \\
\hline 8. All executive board members own shares after excluding options held & $73.1 \%$ \\
\hline 9. All non-executive board members own shares after excluding options held & $37.5 \%$ \\
\hline 10. Company has a separated chairman and CEO & $86.0 \%$ \\
\hline 11. All members attended at least $75 \%$ of the board meetings & $80.5 \%$ \\
\hline 12. Company has a designated "lead" or senior non-executive board member & $28.5 \%$ \\
\hline 13. There have been no related-party transactions in the past three years & $50.0 \%$ \\
\hline 14. The governance/nomination committee is composed of independent board members & $20.9 \%$ \\
\hline 15. No former CEO of the company serves on the board & $72.2 \%$ \\
\hline 16. Nr. of shares held by officers and directors has not decreased by $10 \%$ or more & $84.2 \%$ \\
\hline 17. Nr. of shares held by officers and directors has increased by $10 \%$ or more & $26.0 \%$ \\
\hline 18. Governance/nomination committee has a written charter or terms of reference & $50.6 \%$ \\
\hline 19. Board size is greater than five but less than 16 & $80.5 \%$ \\
\hline 20. Board is controlled by more than $50 \%$ of independent outside directors & $40.7 \%$ \\
\hline \multicolumn{2}{|l|}{ Financial Disclosure and Internal Control } \\
\hline 21. Company has not had a material earnings restatement in the past three years & $98.3 \%$ \\
\hline 22. Audit committee has a written charter or terms of reference & $63.9 \%$ \\
\hline 23. Company has not received a qualified audit opinion within the last two fiscal years & $99.4 \%$ \\
\hline 24. Company is not currently under investigation for accounting irregularities & $98.8 \%$ \\
\hline 25. Audit committee is wholly composed of independent board members & $43.8 \%$ \\
\hline 26. Someone other than senior management with sole authority to hire outside auditor & $85.1 \%$ \\
\hline 27. Audit committee with sole authority to approve non-audit services from outside auditor & $41.9 \%$ \\
\hline 28. Company did not pay its auditor less for audit related services than for other services & $84.4 \%$ \\
\hline \multicolumn{2}{|l|}{ Shareholder Rights } \\
\hline 29. Vote results for the last shareholder meeting are disclosed within 14 calendar days & $78.5 \%$ \\
\hline 30. All common or ordinary equity shares have one-share, one-vote, with no restrictions & $68.0 \%$ \\
\hline 31. The company provides confidential voting with no or with reasonable exceptions & $50.5 \%$ \\
\hline 32. Shareholders have a right to convene an EGM with $10 \%$ or less of the shares requesting one & $90.8 \%$ \\
\hline 33. Shareowners have a right to act in concert through written communication & $17.6 \%$ \\
\hline 34. Voting rights are not capped at a certain percentage & $95.4 \%$ \\
\hline \multicolumn{2}{|l|}{ Remuneration } \\
\hline 35. Non-executive board members paid in cash and some form of stock-linked compensation & $18.1 \%$ \\
\hline 36. Company discloses performance targets for the next fiscal year & $31.1 \%$ \\
\hline 37. Non-executive board members are paid entirely in some form of stock-linked compensation & $0.5 \%$ \\
\hline 38. CEO without an employment agreement that provides for guaranteed bonus payments & $97.9 \%$ \\
\hline 39. Goals used to determine incentive awards are aligned with the company's financial goals & $44.7 \%$ \\
\hline 40. CEO/Managing Director does not sit on the remuneration committee & $94.9 \%$ \\
\hline 41. Remuneration committee is wholly composed of independent board members & $35.9 \%$ \\
\hline 42. No repricing of outstanding executive stock options and no option exchange program & $98.9 \%$ \\
\hline 43. Expensing of employee stock option grants & $35.5 \%$ \\
\hline 44. Remuneration committee has a written charter or terms of reference & $56.4 \%$ \\
\hline
\end{tabular}




\section{Market for Control}

47. Company has not adopted a shareholder rights plan ("poison pill") 96.3\%

48. Company does not have a staggered ("classified") board $51.4 \%$

49. Company cannot issue blank check preferred stock in the event of a hostile tender offer $89.5 \%$

50. Company's shareholder rights plan ("poison pill") has been ratified by a shareholder vote $3.4 \%$

51. Fair price provision in place or price protection under applicable law $69.9 \%$

52. Shareholder rights plan includes a TIDE provision or a three-year sunset provision $1.1 \%$

53. Company does not require a supermajority vote to approve a merger $\quad 42.7 \%$

54. No single shareholder or shareholder group whit majority of voting power $\quad 81.3 \%$

55. Company allows cumulative voting in the election of directors $3.8 \%$

\section{Corporate Behavior}

56. The company have a policy addressing workplace safety $86.0 \%$

57. Company does not have pending criminal litigation against it $96.4 \%$

58. No allegation that the company used sweat shops within the last three years $99.8 \%$

59. Company discloses its environmental performance $52.2 \%$

60. Company discloses its workplace safety record $34.7 \%$

61. No regulatory investigation for a material issue other than for accounting irregularities $91.9 \%$

62. Company discloses its policy regarding corporate level political donations $27.5 \%$

63. Company has not been charged with workplace safety violations within the last two years $\quad 98.7 \%$

64. It has not been alleged by a responsible party that the company used child labor $\quad 99.7 \%$

The table displays the 64 governance attributes of our sample grouped by the six sub-categories: Board Accountability, Financial Disclosure and Internal Control, Shareholder Rights, Remuneration, Market for Control and Corporate Behavior. For each governance attribute we report the percentage of firms in our sample that meet the respective criteria associated with this attribute. The sample consists of 6,663 firm years. 
Table 3: Summary statistics of corporate governance indices and control variables

\begin{tabular}{|c|c|c|c|c|c|c|}
\hline \multicolumn{7}{|c|}{ Panel A: Corporate governance indices } \\
\hline Variable & Obs. & Mean & Median & Std. Dev. & Min & Max \\
\hline CGI1 & 6,663 & 61.47 & 60.71 & 11.12 & 25.00 & 89.06 \\
\hline CGI2 & 6,663 & 53.32 & 50.77 & 13.31 & 16.92 & 87.69 \\
\hline CGI3 & 5,627 & -0.13 & -0.03 & 1.72 & -3.14 & 3.89 \\
\hline \multicolumn{7}{|c|}{ Panel B: Financial data } \\
\hline Variable & Obs. & Mean & Median & Std. Dev. & Min & Max \\
\hline$Q$ & 6,663 & 1.59 & 1.32 & 0.78 & 0.54 & 5.95 \\
\hline LNTA & 6,663 & 8.84 & 8.57 & 1.69 & 4.80 & 15.14 \\
\hline PGSALES & 6,581 & 0.37 & 0.25 & 0.57 & -0.57 & 3.61 \\
\hline RD/SALES & 6,647 & 0.02 & 0.00 & 0.06 & 0.00 & 2.32 \\
\hline CASH/ASSETS & 5,879 & 0.08 & 0.05 & 0.09 & 0.00 & 0.83 \\
\hline CAPEX/ASSETS & 6,594 & 0.05 & 0.04 & 0.06 & 0.00 & 1.64 \\
\hline PPE/SALES & 6,541 & 0.94 & 0.28 & 2.30 & 0.00 & 14.84 \\
\hline EBIT/SALES & 6,604 & 0.21 & 0.12 & 0.30 & 0.00 & 1.88 \\
\hline LEVERAGE & 6,663 & 0.59 & 0.60 & 0.23 & 0.00 & 0.99 \\
\hline ADR & 6,663 & 0.26 & 0.00 & 0.44 & 0.00 & 1.00 \\
\hline CLOSELY HELD & 6,343 & 0.28 & 0.24 & 0.22 & 0.00 & 100.00 \\
\hline
\end{tabular}

The table provides summary statistics for the corporate governance indices (Panel A) and the financial data used in the analysis (Panel B). CGI1 denotes the governance index constructed in the same way as Aggarwal et al. (2009), namely by dividing the governance attributes a company fulfills by the number of governance attributes a company reports data for. CGI2 denotes the governance index constructed in the same way as CGI1 but with missing attributes treated as if these attributes were not fulfilled. CGI3 denotes the governance index constructed by means of principal component analysis (PCA). Q denotes Tobin's Q and is computed as the sum of total assets less the book value of equity plus the market value of equity, divided by total assets, LNTA denotes the logarithm of total assets, PGSALES denotes the two-year growth of sales, RD/SALES denotes the ratio of expenditures for research and development to sales, CASH/ASSETS denotes the ratio of cash to total assets, CAPEX/ASSETS denotes the ratio of capital expenditures to assets, PPE/SALES denotes the ratio of property-plants-equipment to sales, EBIT/SALES denotes the ratio of earnings before interest and taxes to sales, LEVERAGE denotes the ratio of total debt to total assets, ADR is a dummy variable which equals 1 if the firm has American Depository Receipts (ADR) and 0 otherwise, CLOSELY HELD is the percentage of closely held shares. 
Table 4: Corporate governance indices based on principal component analysis (PCA)

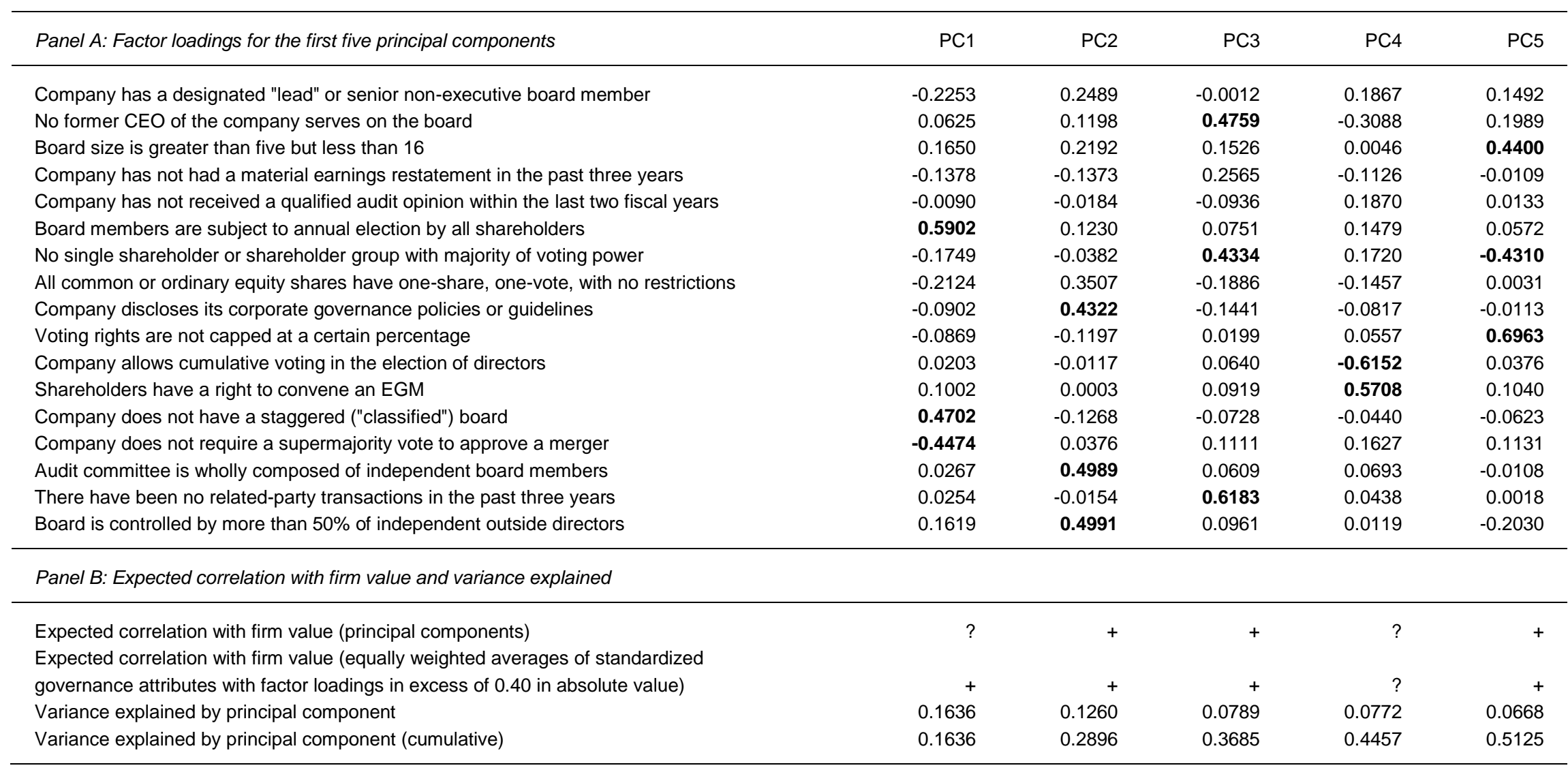

Panel A of the table reports the factor loadings of the 17 governance attributes included in the principal components analysis (PCA) for the first five principal components. These five principal components are used as corporate governance indices (CGI_PCA17_1 (= CGI3) to CGI_PCA17_5). Figures in bold print exhibit factor loadings in excess of 0.40 in absolute terms. To construct a set of alternative PCA-based governance indices, we follow the approach proposed by Larcker et al. (2007) and calculate the equally weighted averages of standardized versions of the governance attributes with factor loadings in excess of 0.40 in absolute terms. Panel B reports the expected sign of the correlation between the PCAbased governance indices and firm value. The expected sign is derived from the signs and magnitudes of the factor loadings of the individual governance attributes in each component. For the governance indices directly based on the first five principal components, we sum all factor loadings over the 17 governance attributes and attribute a positive expectation for the principal components with a value larger than one (the sums of factor loadings for the five components are $0.24,2.06,1.96,0.30$, and 1.09 , respectively). For the governance indices based on the equally weighted averages of the standardized attributes, we derive the sign of the expected correlation from whether the sum of factor loadings in excess of 0.40 in absolute terms is larger than zero (larger than 0.5), smaller than zero (smaller than -0.5), or close to zero (between -0.5 and 0.5 ). 
Table 5: Fixed effects regressions of Tobin's $Q$ on alternative governance indices and control variables

\begin{tabular}{|c|c|c|c|c|c|c|c|c|}
\hline \multirow[t]{2}{*}{ Dependent Variable: Tobin's $Q$} & \multicolumn{3}{|c|}{ Standard Specification } & \multicolumn{3}{|c|}{ Country, Industry and Year FE } & \multicolumn{2}{|c|}{ Country-Adjusted CGI } \\
\hline & (1) & (2) & (3) & (4) & (5) & (6) & (7) & (8) \\
\hline Constant & $\begin{array}{l}2.827^{\star \star *} \\
(0.000)\end{array}$ & $\begin{array}{l}3.128^{* * *} \\
(0.000)\end{array}$ & $\begin{array}{l}3.155^{* * *} \\
(0.000)\end{array}$ & $\begin{array}{l}1.718^{* * *} \\
(0.000)\end{array}$ & $\begin{array}{l}1.578^{* * *} \\
(0.000)\end{array}$ & $\begin{array}{l}2.057^{* * *} \\
(0.000)\end{array}$ & $\begin{array}{l}2.799^{* * *} \\
(0.000)\end{array}$ & $\begin{array}{l}3.076^{* * *} \\
(0.000)\end{array}$ \\
\hline CGl1 & $\begin{array}{l}0.005^{* *} \\
(0.042)\end{array}$ & & & $\begin{array}{l}0.006^{* * *} \\
(0.001)\end{array}$ & & & $\begin{array}{l}0.013^{* * *} \\
(0.000)\end{array}$ & \\
\hline CGI2 & & $\begin{array}{l}0.011^{* * *} \\
(0.000)\end{array}$ & & & $\begin{array}{l}0.009^{* * *} \\
(0.000)\end{array}$ & & & $\begin{array}{l}0.021^{* * \star} \\
(0.000)\end{array}$ \\
\hline CGI3 & & & $\begin{array}{l}0.045^{* * *} \\
(0.000)\end{array}$ & & & $\begin{array}{l}0.025^{* *} \\
(0.037)\end{array}$ & & \\
\hline LNTA & $\begin{array}{l}-0.195^{* * *} \\
(0.000)\end{array}$ & $\begin{array}{l}-0.288^{* * *} \\
(0.000)\end{array}$ & $\begin{array}{l}-0.198^{* * *} \\
(0.000)\end{array}$ & $\begin{array}{l}-0.174^{* * *} \\
(0.000)\end{array}$ & $\begin{array}{l}-0.180^{* * *} \\
(0.000)\end{array}$ & $\begin{array}{l}-0.172^{* * *} \\
(0.000)\end{array}$ & $\begin{array}{l}-0.269^{* * *} \\
(0.000)\end{array}$ & $\begin{array}{l}-0.286^{* * *} \\
(0.000)\end{array}$ \\
\hline PGSALES & $\begin{array}{l}-0.002 \\
(0.877)\end{array}$ & $\begin{array}{r}0.011 \\
(0.362)\end{array}$ & $\begin{array}{l}-0.027^{*} \\
(0.061)\end{array}$ & $\begin{array}{l}0.104^{\text {***}} \\
(0.000)\end{array}$ & $\begin{array}{l}0.106^{* * *} \\
(0.000)\end{array}$ & $\begin{array}{c}0.090^{* * *} \\
(0.000)\end{array}$ & $\begin{array}{r}0.009 \\
(0.410)\end{array}$ & $\begin{array}{r}0.012 \\
(0.285)\end{array}$ \\
\hline RD/SALES & $\begin{array}{l}-0.044 \\
(0.872)\end{array}$ & $\begin{array}{l}-0.094 \\
(0.723)\end{array}$ & $\begin{array}{r}0.125 \\
(0.447)\end{array}$ & $\begin{array}{l}1.120^{* * *} \\
(0.004)\end{array}$ & $\begin{array}{l}1.105^{* * *} \\
(0.005)\end{array}$ & $\begin{array}{l}0.990^{* * *} \\
(0.001)\end{array}$ & $\begin{array}{l}-0.079 \\
(0.769)\end{array}$ & $\begin{array}{l}-0.090 \\
(0.736)\end{array}$ \\
\hline CASH/SALES & $\begin{array}{l}0.345^{* * *} \\
(0.000)\end{array}$ & $\begin{array}{l}0.334^{* * *} \\
(0.000)\end{array}$ & $\begin{array}{l}0.271^{* * *} \\
(0.001)\end{array}$ & $\begin{array}{l}1.420^{* * *} \\
(0.000)\end{array}$ & $\begin{array}{l}1.412^{* * *} \\
(0.000)\end{array}$ & $\begin{array}{l}1.380^{* * *} \\
(0.000)\end{array}$ & $\begin{array}{l}0.352^{* * *} \\
(0.000)\end{array}$ & $\begin{array}{l}0.340^{* * *} \\
(0.000)\end{array}$ \\
\hline CAPEX/ASSETS & $\begin{array}{l}0.532^{* * *} \\
(0.000)\end{array}$ & $\begin{array}{l}0.446 \text { *** } \\
(0.000)\end{array}$ & $\begin{array}{l}0.603^{* * *} \\
(0.000)\end{array}$ & $\begin{array}{l}0.932^{\star * *} \\
(0.001)\end{array}$ & $\begin{array}{l}0.922^{* * *} \\
(0.001)\end{array}$ & $\begin{array}{l}0.952^{\star \star *} \\
(0.001)\end{array}$ & $\begin{array}{l}0.475^{\star * *} \\
(0.000)\end{array}$ & $\begin{array}{l}0.447^{\text {*** }} \\
(0.000)\end{array}$ \\
\hline PPE/SALES & $\begin{array}{l}-0.052^{* * *} \\
(0.000)\end{array}$ & $\begin{array}{l}-0.044^{* * *} \\
(0.000)\end{array}$ & $\begin{array}{l}-0.049^{* * *} \\
(0.000)\end{array}$ & $\begin{array}{l}-0.068^{* * *} \\
(0.000)\end{array}$ & $\begin{array}{l}-0.067^{* * *} \\
(0.000)\end{array}$ & $\begin{array}{l}-0.067^{* * *} \\
(0.000)\end{array}$ & $\begin{array}{l}-0.046^{* * *} \\
(0.000)\end{array}$ & $\begin{array}{l}-0.044^{* * *} \\
(0.000)\end{array}$ \\
\hline EBIT/SALES & $\begin{array}{l}0.218^{* * *} \\
(0.000)\end{array}$ & $\begin{array}{l}0.192^{* * *} \\
(0.000)\end{array}$ & $\begin{array}{l}0.174^{* * *} \\
(0.000)\end{array}$ & $\begin{array}{l}0.485^{\star * *} \\
(0.000)\end{array}$ & $\begin{array}{l}0.491^{* * *} \\
(0.000)\end{array}$ & $\begin{array}{l}0.455^{* * *} \\
(0.000)\end{array}$ & $\begin{array}{l}0.196^{* * *} \\
(0.000)\end{array}$ & $\begin{array}{l}0.191^{\text {*** }} \\
(0.000)\end{array}$ \\
\hline LEVERAGE & $\begin{array}{l}-0.187^{\star * *} \\
(0.001)\end{array}$ & $\begin{array}{l}-0.011 \\
(0.898)\end{array}$ & $\begin{array}{l}-0.096 \text { * } \\
(0.081)\end{array}$ & $\begin{array}{l}0.117^{\star * \star} \\
(0.002)\end{array}$ & $\begin{array}{l}0.125^{* * *} \\
(0.001)\end{array}$ & $\begin{array}{l}0.179^{\star * *} \\
(0.000)\end{array}$ & $\begin{array}{l}-0.054 \\
(0.442)\end{array}$ & $\begin{array}{l}-0.015 \\
(0.848)\end{array}$ \\
\hline ADR & $\begin{array}{l}1.036^{* * *} \\
(0.000)\end{array}$ & $\begin{array}{l}1.477^{\star * *} \\
(0.000)\end{array}$ & $\begin{array}{l}1.020^{* * *} \\
(0.000)\end{array}$ & $\begin{array}{l}0.161^{* * *} \\
(0.000)\end{array}$ & $\begin{array}{l}0.152^{* * *} \\
(0.000)\end{array}$ & $\begin{array}{l}0.170^{* * *} \\
(0.000)\end{array}$ & $\begin{array}{l}1.416^{* * *} \\
(0.000)\end{array}$ & $\begin{array}{l}1.466^{* * *} \\
(0.000)\end{array}$ \\
\hline CLOSELY HELD & $\begin{array}{l}-0.001^{* * *} \\
(0.001)\end{array}$ & $\begin{array}{l}-0.001^{* * *} \\
(0.010)\end{array}$ & $\begin{array}{l}-0.0011^{* * *} \\
(0.000)\end{array}$ & $\begin{array}{l}0.002^{* * *} \\
(0.000)\end{array}$ & $\begin{array}{l}0.002^{\text {***}} \\
(0.000)\end{array}$ & $\begin{array}{l}0.001^{\text {*** }} \\
(0.005)\end{array}$ & $\begin{array}{l}-0.001 \text { ** } \\
(0.011)\end{array}$ & $\begin{array}{l}-0.001^{\text {***}} \\
(0.009)\end{array}$ \\
\hline R-squared (within) & 0.057 & 0.099 & 0.059 & - & - & - & 0.091 & 0.100 \\
\hline R-squared & - & - & - & 0.304 & 0.307 & 0.293 & - & - \\
\hline Firms & 1,625 & 1,625 & 1,497 & 1,625 & 1,625 & 1,497 & 1,625 & 1,625 \\
\hline Observations & 5,453 & 5,453 & 4,630 & 5,453 & 5,453 & 4,630 & 5,453 & 5,453 \\
\hline
\end{tabular}




\section{Table 5 - continued}

The table reports estimates from fixed effects regressions of Tobin's $\mathrm{Q}$ on alternative corporate governance indices and control variables. CGI1 denotes the governance index constructed in the same way as Aggarwal et al. (2009), namely by dividing the governance attributes a company fulfills by the number of governance attributes a company reports data for. CGI2 denotes the governance index constructed in the same way as CGI1 but with missing attributes treated as if these attributes were not fulfilled. CGI3 denotes the governance index constructed by means of principal component analysis (PCA). LNTA denotes the logarithm of total assets, PGSALES denotes the two-year growth of sales, RD/SALES denotes the ratio of expenditures for research and development to sales, CASH/ASSETS denotes the ratio of cash to total assets, CAPEX/ASSETS denotes the ratio of capital expenditures to assets, PPE/SALES denotes the ratio of property-plants-equipments to sales, EBIT/SALES denotes the ratio of earnings before interest and taxes to sales, LEVERAGE denotes the ratio of total debt to total assets, ADR is a dummy variable which equals 1 if the firm has American Depository Receipts (ADR) and 0 otherwise, CLOSELY HELD is the percentage of closely held shares. The regressions reported in Columns 1 to 3 and 7 and 8 use our standard specification and firm fixed effects, the regressions in Columns 4 to 7 use industry, year, and country fixed effects. For the regressions in Columns 7 and 8 , we adjust the CGI1 and CGI2 scores in a way proposed by Chhaochharia and Laeven (2009) and subtract the number of governance attributes that every firm in a given country fulfills in a given year. The $p$-values (in parentheses) are based on Driscoll and Kraay (1998) standard errors which are heteroskedasticity-consistent and robust to general forms of cross-sectional and temporal dependence. $* * * * *, *$ denotes statistical significance at the $1 \%, 5 \%, 10 \%$ level. 
Table 6: Fixed effects regressions of Tobin's Q on CGI1 by year and country

\begin{tabular}{|c|c|c|c|c|c|c|c|c|c|c|}
\hline \multicolumn{11}{|c|}{ Dependent Variable: Tobin's Q } \\
\hline \multirow[t]{2}{*}{ Sample restricted to: } & 2003 & 2004 & 2005 & 2006 & 2007 & Japan & U.K. & Canada & Australia & France \\
\hline & (1) & (2) & (3) & (4) & (5) & (6) & (7) & (8) & (9) & (10) \\
\hline \multirow[t]{2}{*}{ Constant } & $1.801^{* * *}$ & $2.095^{* * *}$ & $2.015^{* \star *}$ & 2.516 *** & $2.174^{* * *}$ & 1.006 & $2.409 * \star \star$ & $3.672^{* * *}$ & $1.771^{\star * *}$ & $7.024^{* * *}$ \\
\hline & $(0.000)$ & $(0.000)$ & $(0.000)$ & $(0.000)$ & $(0.000)$ & $(0.172)$ & $(0.000)$ & $(0.000)$ & $(0.000)$ & $(0.000)$ \\
\hline \multirow[t]{2}{*}{ CGl1 } & 0.002 & $0.008^{* * *}$ & $0.012^{* * *}$ & $0.009^{* * *}$ & $0.010^{* * *}$ & -0.004 & $0.014^{* * *}$ & $0.008^{* *}$ & $0.027^{* * *}$ & $0.010^{* * *}$ \\
\hline & $(0.576)$ & $(0.000)$ & $(0.000)$ & $(0.000)$ & $(0.000)$ & $(0.118)$ & $(0.000)$ & $(0.042)$ & $(0.000)$ & $(0.000)$ \\
\hline \multirow[t]{2}{*}{ LNTA } & $-0.098^{* * *}$ & $-0.179^{* * *}$ & $-0.191^{* * *}$ & $-0.200^{* * *}$ & $-0.170^{* * *}$ & 0.148 & $-0.281^{* * *}$ & -0.149 * & $-0.212^{* * *}$ & $-0.675^{* * *}$ \\
\hline & $(0.000)$ & $(0.000)$ & $(0.000)$ & $(0.000)$ & $(0.000)$ & $(0.109)$ & $(0.000)$ & $(0.052)$ & $(0.000)$ & $(0.000)$ \\
\hline \multirow[t]{2}{*}{ PGSALES } & $0.251^{* * *}$ & $0.079^{* *}$ & 0.099 * & $0.084^{* *}$ & $0.172^{* * *}$ & -0.006 & $0.049^{* * *}$ & 0.011 & $-0.103^{* *}$ & -0.024 \\
\hline & $(0.004)$ & $(0.043)$ & $(0.072)$ & $(0.022)$ & $(0.000)$ & $(0.907)$ & $(0.000)$ & $(0.595)$ & $(0.017)$ & $(0.408)$ \\
\hline \multirow[t]{2}{*}{ RD/SALES } & $4.578^{* * *}$ & $1.759^{* *}$ & $2.632^{* \star *}$ & 0.632 & 0.633 & $-2.772^{* *}$ & $0.206^{* *}$ & $-7.480^{* * *}$ & -10.419 & 0.533 \\
\hline & $(0.000)$ & $(0.040)$ & $(0.004)$ & $(0.291)$ & $(0.167)$ & $(0.045)$ & $(0.028)$ & $(0.001)$ & $(0.354)$ & $(0.348)$ \\
\hline \multirow[t]{2}{*}{ CASH/ASSETS } & 0.362 & $1.487^{\text {***}}$ & $0.777^{* *}$ & $1.425^{* * *}$ & $0.902^{* * *}$ & 0.437 & $-0.241^{* *}$ & & $2.076^{* \star *}$ & $0.987^{* * *}$ \\
\hline & $(0.656)$ & $(0.000)$ & $(0.010)$ & $(0.000)$ & $(0.006)$ & $(0.118)$ & $(0.043)$ & & $(0.000)$ & $(0.000)$ \\
\hline \multirow[t]{2}{*}{ CAPEX/ASSETS } & 0.286 & 0.706 & 0.694 & $1.938^{* * *}$ & $2.260^{* * *}$ & $1.205^{* * *}$ & $-0.766^{* *}$ & $2.861^{* * *}$ & $0.527^{* *}$ & 0.256 \\
\hline & $(0.481)$ & $(0.116)$ & $(0.160)$ & $(0.003)$ & $(0.001)$ & $(0.000)$ & $(0.048)$ & $(0.001)$ & $(0.048)$ & $(0.526)$ \\
\hline \multirow[t]{2}{*}{ PPE/SALES } & $-0.159^{* * *}$ & $-0.068^{* * *}$ & $-0.086^{* * *}$ & $-0.087^{\star \star \star *}$ & $-0.078^{* \star *}$ & $-0.150^{* * *}$ & $-0.036^{\star \star *}$ & $-0.222^{* \star *}$ & $-0.013^{* * *}$ & $-0.754^{* * *}$ \\
\hline & $(0.000)$ & $(0.000)$ & $(0.000)$ & $(0.000)$ & $(0.000)$ & $(0.001)$ & $(0.002)$ & $(0.000)$ & $(0.001)$ & $(0.000)$ \\
\hline \multirow[t]{2}{*}{ EBIT/SALES } & $1.715^{* * *}$ & $0.490^{* * *}$ & $0.542^{* * *}$ & $0.406^{* * *}$ & $0.322^{* * *}$ & $0.284^{* * *}$ & $0.208^{* * *}$ & -0.139 & $-0.197^{* * *}$ & $1.764^{* * *}$ \\
\hline & $(0.001)$ & $(0.003)$ & $(0.000)$ & $(0.001)$ & $(0.000)$ & $(0.000)$ & $(0.000)$ & $(0.169)$ & $(0.000)$ & $(0.000)$ \\
\hline \multirow[t]{2}{*}{ LEVERAGE } & 0.009 & 0.186 & 0.204 & 0.072 & -0.036 & $-1.243^{* * *}$ & $0.386^{* *}$ & $-1.641^{* * *}$ & 0.079 & 0.867 \\
\hline & $(0.966)$ & $(0.159)$ & $(0.127)$ & $(0.595)$ & $(0.789)$ & $(0.000)$ & $(0.013)$ & $(0.000)$ & $(0.608)$ & $(0.100)$ \\
\hline \multirow[t]{2}{*}{ ADR } & $0.198^{* * *}$ & $0.164^{* * *}$ & $0.137^{\star * *}$ & $0.168^{* \star *}$ & $0.195^{* * *}$ & & $1.697^{\star \star *}$ & & & \\
\hline & $(0.000)$ & $(0.001)$ & $(0.002)$ & $(0.000)$ & $(0.000)$ & & $(0.000)$ & & & \\
\hline \multirow[t]{2}{*}{ CLOSELY HELD } & 0.001 & $0.004^{* * *}$ & $0.005^{* * *}$ & $0.002^{* *}$ & $0.003^{* * *}$ & 0.001 & $-0.004^{* * *}$ & $-0.004^{*}$ & 0.001 & $0.006^{* *}$ \\
\hline & $(0.600)$ & $(0.000)$ & $(0.000)$ & $(0.033)$ & $(0.004)$ & $(0.521)$ & $(0.000)$ & $(0.054)$ & $(0.226)$ & $(0.015)$ \\
\hline R-squared & 0.308 & 0.260 & 0.263 & 0.256 & 0.218 & - & - & - & - & - \\
\hline R-squared (within) & - & - & - & - & - & 0.113 & 0.129 & 0.265 & 0.188 & 0.477 \\
\hline Firms & 460 & 1,127 & 1,149 & 1,336 & 1,381 & 411 & 369 & 143 & 101 & 95 \\
\hline Observations & 460 & 1,127 & 1,149 & 1,336 & 1,381 & 1,642 & 1,195 & 388 & 346 & 307 \\
\hline
\end{tabular}




\section{Table 6 - continued}

The table reports estimates from regressions of Tobin's Q on CGI1 and control variables for single years and countries. In Columns 1 to 5 , the sample is divided in sub-samples based on calendar years. Column 1 reports the results for 2003, Column 2 for 2004, Column 3 for 2005, Column 4 for 2006, and Column 5 for 2007. Columns 6 to 10 break down the sample by country. Column 6 contains only U.K., Column 7 Canadian, Column 8 Australian, Column 9 French, and Column 10 German firms. CGI1 denotes the governance index constructed in the same way as Aggarwal et al. (2009), namely by dividing the governance attributes a company fulfills by the number of governance attributes a company reports data for. LNTA denotes the logarithm of total assets, PGSALES denotes the two-year growth of sales, RD/SALES denotes the ratio of expenditures for research and development to sales, CASH/ASSETS denotes the ratio of cash to total assets,

CAPEX/ASSETS denotes the ratio of capital expenditures to assets, PPE/SALES denotes the ratio of property-plants-equipments to sales, EBIT/SALES denotes the ratio of earnings before interest and taxes to sales, LEVERAGE denotes the ratio of total debt to total assets, ADR is a dummy variable which equals 1 if the firm has American Depository Receipts (ADR) and 0 otherwise, CLOSELY HELD is the percentage of closely held shares. The dummy variable whether the firm has American Depository Receipts, ADR, is dropped from the regressions reported in Columns 7 to 10 as there is no time-series variability in the variable. The regressions in Columns 6 to 10 include firm fixed effects. The $p$-values (in parentheses) in Columns 1 to 5 are based on White (1980) standard errors which are heteroskedasticity-consistent. The $p$-values (in parentheses) in Columns 6 to 10 are based on Driscoll and Kraay (1998) standard errors which are heteroskedasticityconsistent and robust to general forms of cross-sectional and temporal dependence. $* * * * *, *$ denotes statistical significance at the $1 \%, 5 \%, 10 \%$ level. 
Table 7: Fixed effects regressions of Tobin's $Q$ on alternative PCA-based governance indices

\begin{tabular}{|c|c|c|c|c|c|c|c|}
\hline \multicolumn{8}{|c|}{ Dependent Variable: Tobin's $Q$} \\
\hline & (1) & (2) & (3) & (4) & (5) & (6) & (7) \\
\hline \multirow[t]{2}{*}{ Constant } & $3.177^{* * *}$ & $3.043^{* * *}$ & $3.214^{* * *}$ & $3.230^{* * *}$ & $3.242^{* \star \star}$ & $3.037^{\star \star * *}$ & $3.211^{* \star \star}$ \\
\hline & $(0.000)$ & $(0.000)$ & $(0.000)$ & $(0.000)$ & $(0.000)$ & $(0.000)$ & $(0.000)$ \\
\hline \multirow[t]{2}{*}{ CGI_PCA17_1 ( = CGI3) } & $0.037^{* * *}$ & & & & & & \\
\hline & $(0.000)$ & & & & & & \\
\hline \multirow[t]{2}{*}{ CGI_PCA17_2 } & $0.042^{* * *}$ & & & & & & \\
\hline & $(0.010)$ & & & & & & \\
\hline \multirow[t]{2}{*}{ CGI_PCA17_3 } & -0.000 & & & & & & \\
\hline & $(0.974)$ & & & & & & \\
\hline \multirow[t]{2}{*}{ CGI_PCA17_4 } & $0.033^{* * *}$ & & & & & & \\
\hline & $(0.000)$ & & & & & & \\
\hline \multirow[t]{2}{*}{ CGI_PCA17_5 } & 0.001 & & & & & & \\
\hline & $(0.865)$ & & & & & & \\
\hline \multirow[t]{2}{*}{ CGI_PCA17L_1 } & & $0.062^{* * *}$ & $0.066^{\star \star \star}$ & & & & \\
\hline & & $(0.001)$ & $(0.000)$ & & & & \\
\hline \multirow[t]{2}{*}{ CGI_PCA17L_2 } & & & $0.068^{* * *}$ & & & & \\
\hline & & & $(0.000)$ & & & & \\
\hline \multirow[t]{2}{*}{ CGI_PCA17L_3 } & & & 0.008 & & & & \\
\hline & & & $(0.668)$ & & & & \\
\hline \multirow[t]{2}{*}{ CGI_PCA17L_4 } & & & $0.051^{* * *}$ & & & & \\
\hline & & & $(0.000)$ & & & & \\
\hline \multirow{2}{*}{ CGI_PCA17L_5 } & & & $0.028^{* * *}$ & & & & \\
\hline & & & $(0.000)$ & & & & \\
\hline \multirow[t]{2}{*}{ CGI_PCA21_1 } & & & & $0.041^{* * *}$ & $0.034^{* * *}$ & & \\
\hline & & & & $(0.000)$ & $(0.000)$ & & \\
\hline \multirow[t]{2}{*}{ CGI_PCA21_2 } & & & & & $-0.042^{* *}$ & & \\
\hline & & & & & $(0.040)$ & & \\
\hline \multirow[t]{2}{*}{ CGI_PCA21_3 } & & & & & 0.021 & & \\
\hline & & & & & $(0.102)$ & & \\
\hline \multirow[t]{2}{*}{ CGI_PCA21_4 } & & & & & $-0.012^{* * *}$ & & \\
\hline & & & & & $(0.003)$ & & \\
\hline \multirow[t]{2}{*}{ CGI_PCA21_5 } & & & & & 0.011 & & \\
\hline & & & & & $(0.206)$ & & \\
\hline \multirow[t]{2}{*}{ CGI_PCA21L_1 } & & & & & & $0.061^{* * *}$ & $0.064^{* \star \star}$ \\
\hline & & & & & & $(0.001)$ & $(0.001)$ \\
\hline \multirow[t]{2}{*}{ CGI_PCA21L_2 } & & & & & & & $0.069^{* * *}$ \\
\hline & & & & & & & $(0.000)$ \\
\hline \multirow[t]{2}{*}{ CGI_PCA21L_3 } & & & & & & & 0.008 \\
\hline & & & & & & & $(0.670)$ \\
\hline \multirow[t]{2}{*}{ CGI_PCA21L_4 } & & & & & & & $0.049^{* * *}$ \\
\hline & & & & & & & $(0.000)$ \\
\hline \multirow[t]{2}{*}{ CGI_PCA21L_5 } & & & & & & & $0.028^{* * \star}$ \\
\hline & & & & & & & $(0.000)$ \\
\hline R-squared (within) & 0.065 & 0.053 & 0.067 & 0.072 & 0.076 & 0.053 & 0.066 \\
\hline Firms & 1,497 & 1,571 & 1,499 & 1,316 & 1,316 & 1,571 & 1,499 \\
\hline Observations & 4,630 & 5,057 & 4,647 & 3,828 & 3,828 & 5,057 & 4,647 \\
\hline
\end{tabular}

The table reports estimates from fixed effects regressions of Tobin's Q on alternative corporate governance indices and control variables. To save space, the coefficients on the control variables are not reported in the table. Variables CGI_PCA17_1 to CGI_PCA17_5 denote the first five principal components obtained from principal component analysis using 17 governance attributes. Variables CGI_PCA17L_1 to CGI_PCA17L_5 denote the components obtained by following Larcker et al. (2007) using 17 governance attributes. Variables CGI_PCA21_1 to CGI_PCA21_5 denote the first five principal components obtained from principal component analysis using 21 governance attributes. Variables CGI_PCA21L_1 to CGI_PCA21L_5 denote are the components obtained by following Larcker et al. (2007) using 21 governance attributes. All regressions include firm fixed effects. The $p$-values (in parentheses) are based on Driscoll and Kraay (1998) standard errors which are heteroskedasticity-consistent and robust to general forms of cross-sectional and temporal dependence. ***, **, * denotes statistical significance at the $1 \%, 5 \%, 10 \%$ level. 
Table 8: Fixed effects regressions of Tobin's $Q$ on corporate social responsibility indices, governance indices, and control variables

\begin{tabular}{|c|c|c|c|c|c|c|c|}
\hline \multicolumn{8}{|c|}{ Dependent variable: Tobin's $Q$} \\
\hline & \multicolumn{3}{|c|}{ Standard specifications } & \multicolumn{2}{|c|}{ Industry, country, and year FE } & \multicolumn{2}{|c|}{ Interaction terms } \\
\hline & $(1)$ & $(2)$ & (3) & (4) & $(5)$ & (6) & $(7)$ \\
\hline \multirow[t]{2}{*}{ Constant } & $3.166^{* * *}$ & $2.420^{* * *}$ & $3.162^{* * *}$ & $1.567^{\star \star \star}$ & $1.626^{* * *}$ & $3.415^{\star \star \star}$ & $3.222^{* \star *}$ \\
\hline & $(0.000)$ & $(0.001)$ & $(0.000)$ & $(0.000)$ & $(0.000)$ & $(0.000)$ & $(0.000)$ \\
\hline \multirow[t]{2}{*}{ CSRI } & $0.003^{* * *}$ & & & $0.002^{* * *}$ & & 0.000 & \\
\hline & $(0.000)$ & & & $(0.000)$ & & $(0.956)$ & \\
\hline \multirow[t]{2}{*}{ CSRI_PCA } & & $0.043^{* * *}$ & & & $0.038^{* * *}$ & & -0.001 \\
\hline & & $(0.001)$ & & & $(0.000)$ & & $(0.592)$ \\
\hline \multirow[t]{2}{*}{ CSRI_ADJ } & & & $0.003^{* \star *}$ & & & & \\
\hline & & & $(0.000)$ & & & & \\
\hline \multirow[t]{2}{*}{ CGI_CONTR } & $0.007^{* * *}$ & $0.012^{* * *}$ & $0.007^{* * *}$ & $0.007^{\star * \star}$ & $0.008^{* * *}$ & $0.003^{*}$ & $0.008^{* * *}$ \\
\hline & $(0.000)$ & $(0.000)$ & $(0.000)$ & $(0.000)$ & $(0.000)$ & $(0.053)$ & $(0.000)$ \\
\hline \multirow[t]{2}{*}{ CSRI*CGI_CONTR } & & & & & & $0.000^{* * *}$ & \\
\hline & & & & & & $(0.000)$ & \\
\hline \multirow[t]{2}{*}{ CSRI_PCA ${ }^{*} \mathrm{CGI}$ CONTR } & & & & & & & $0.000^{* *}$ \\
\hline & & & & & & & $(0.036)$ \\
\hline \multirow[t]{2}{*}{ LNTA } & $-0.285^{* * *}$ & $-0.141^{*}$ & $-0.287^{* * *}$ & $-0.182^{* * *}$ & $-0.186^{* * *}$ & $-0.293^{* * *}$ & $-0.283^{* * *}$ \\
\hline & $(0.000)$ & $(0.056)$ & $(0.000)$ & $(0.000)$ & $(0.000)$ & $(0.000)$ & $(0.000)$ \\
\hline \multirow[t]{2}{*}{ PGSALES } & 0.010 & 0.001 & 0.013 & $0.106^{* * *}$ & $0.134^{* * *}$ & 0.015 & 0.009 \\
\hline & $(0.404)$ & $(0.905)$ & $(0.206)$ & $(0.000)$ & $(0.000)$ & $(0.163)$ & $(0.404)$ \\
\hline \multirow[t]{2}{*}{ RD/SALES } & -0.089 & $0.381^{\star \star \star}$ & -0.091 & $1.105^{\text {***}}$ & $0.640^{* * *}$ & -0.100 & -0.094 \\
\hline & $(0.738)$ & $(0.002)$ & $(0.737)$ & $(0.005)$ & $(0.002)$ & $(0.711)$ & $(0.716)$ \\
\hline \multirow[t]{2}{*}{ CASH/ASSETS } & $0.332^{* * *}$ & -0.205 & $0.349^{* \star *}$ & $1.413^{* \star *}$ & $1.524^{\star \star *}$ & $0.314^{\star \star \star *}$ & $0.306^{* * *}$ \\
\hline & $(0.000)$ & $(0.217)$ & $(0.000)$ & $(0.000)$ & $(0.000)$ & $(0.000)$ & $(0.000)$ \\
\hline \multirow[t]{2}{*}{ CAPEX/ASSETS } & $0.438^{* * *}$ & $0.763^{* * *}$ & $0.431^{* * *}$ & $0.914^{* * *}$ & $0.725^{* *}$ & $0.446^{* * *}$ & $0.461^{* * *}$ \\
\hline & $(0.000)$ & $(0.000)$ & $(0.000)$ & $(0.001)$ & $(0.011)$ & $(0.000)$ & $(0.000)$ \\
\hline \multirow[t]{2}{*}{ PPE/SALES } & $-0.044^{* * *}$ & $-0.040^{* * *}$ & $-0.043^{* * *}$ & $-0.067^{* * *}$ & $-0.073^{* * *}$ & $-0.043^{* * *}$ & $-0.045^{* * *}$ \\
\hline & $(0.000)$ & $(0.000)$ & $(0.000)$ & $(0.000)$ & $(0.000)$ & $(0.000)$ & $(0.000)$ \\
\hline \multirow[t]{2}{*}{ EBIT/SALES } & $0.191^{\text {***}}$ & 0.122 * & $0.191^{* \star *}$ & $0.492^{* \star *}$ & $0.447^{* * *}$ & $0.189^{* * *}$ & $0.196^{* * *}$ \\
\hline & $(0.000)$ & $(0.075)$ & $(0.000)$ & $(0.000)$ & $(0.000)$ & $(0.000)$ & $(0.000)$ \\
\hline \multirow[t]{2}{*}{ LEVERAGE } & -0.005 & -0.158 & 0.010 & $0.129^{* * *}$ & -0.032 & -0.026 & -0.050 \\
\hline & $(0.957)$ & $(0.225)$ & $(0.916)$ & $(0.001)$ & $(0.490)$ & $(0.739)$ & $(0.512)$ \\
\hline \multirow[t]{2}{*}{ ADR } & $1.428^{* * *}$ & & $1.405^{* * *}$ & $0.152^{* * *}$ & $0.166^{* * *}$ & $1.460^{* \star *}$ & $1.515^{* * *}$ \\
\hline & $(0.000)$ & & $(0.000)$ & $(0.000)$ & $(0.000)$ & $(0.000)$ & $(0.000)$ \\
\hline \multirow[t]{2}{*}{ CLOSELY HELD } & $-0.001 * * *$ & $-0.002^{* * *}$ & -0.001 *** & $0.002^{* * *}$ & 0.001 *** & -0.001 *** & -0.001 *** \\
\hline & $(0.009)$ & $(0.000)$ & $(0.008)$ & $(0.000)$ & $(0.005)$ & $(0.006)$ & $(0.005)$ \\
\hline R-squared (within) & 0.101 & 0.059 & 0.102 & - & - & 0.103 & 0.095 \\
\hline R-squared & - & - & - & 0.307 & 0.320 & - & - \\
\hline Firms & 1,625 & 1,111 & 1,625 & 1,625 & 1,111 & 1,625 & 1,625 \\
\hline Observations & 5,453 & 2,763 & 5,453 & 5,453 & 2,763 & 5,453 & 5,453 \\
\hline
\end{tabular}

The table reports estimates from fixed effects regressions of Tobin's Q on alternative CSR indices and control variables. CSRI denotes the CSR index constructed in the same way as CGI2, using the nine CSR attributes and treating missing attributes as if they were not in place. CSRI_PCA denotes the CSR index constructed by means of principal component analysis (PCA), using the nine CSR attributes. CSR_ADJ denotes the adjusted CSRI index. The adjustment is similar to the one proposed by Chhaochharia and Laeven (2009), and subtracts the number of CSR attributes that every firm in a given country fulfills in a given year. CGI_CONTR denotes the governance index constructed of the governance attributes that are not part of the company behavior (CSR) category. Columns 6 and 7 additionally include interaction terms between CSRI and CGI_CONTR and between CSRI_PCA and CSRI_CONTR, respectively. LNTA denotes the logarithm of total assets, PGSALES denotes the two-year growth of sales, RD/SALES denotes the ratio of expenditures for research and development to sales, CASH/ASSETS denotes the ratio of cash to total assets, CAPEX/ASSETS denotes the ratio of capital expenditures to assets, PPE/SALES denotes the ratio of property-plants-equipments to sales, EBIT/SALES denotes the ratio of earnings before interest and taxes to sales, LEVERAGE denotes the ratio of total debt to total assets, ADR is a dummy variable which equals 1 if the firm has American Depository Receipts (ADR) and 0 otherwise, CLOSELY HELD is the percentage of closely held shares. The dummy variable whether the firm has American Depository Receipts, ADR, is dropped from the regression reported in Columns 2 as there is no time-series variability in the variable. The regressions reported in Columns 1 to 3 and 6 to 7 use firm fixed effects, the regressions reported in Columns 4 and 5 use industry, country, and year fixed effects. The $p$-values (in parentheses) are based on Driscoll and Kraay (1998) standard errors which are heteroskedasticity-consistent and robust to general forms of cross-sectional and temporal dependence. $* * * * *, *$ denotes statistical significance at the $1 \%, 5 \%, 10 \%$ level. 
Table 9: Dynamic panel GMM and Heckman selection model estimations

\begin{tabular}{|c|c|c|c|c|c|c|c|}
\hline \multicolumn{8}{|c|}{ Dependent variable: Tobin's $Q$} \\
\hline & \multicolumn{5}{|c|}{ Dynamic panel GMM estimations } & \multicolumn{2}{|c|}{ Heckman selection model } \\
\hline & (1) & (2) & (3) & (4) & (5) & (6) & (7) \\
\hline \multirow[t]{2}{*}{ Constant } & $1.475^{* * *}$ & 0.655 & $1.470^{\star \star \star}$ & 0.089 & $4.272^{\star \star \star}$ & $2.593^{* \star \star}$ & $2.561^{\star \star *}$ \\
\hline & $(0.003)$ & $(0.206)$ & $(0.009)$ & $(0.855)$ & $(0.000)$ & $(0.000)$ & $(0.000)$ \\
\hline \multirow[t]{2}{*}{ Lagged Tobin's Q } & $0.842 * * *$ & $0.870^{\star * *}$ & $0.896^{* * *}$ & $0.874^{\star \star *}$ & $0.664^{* * *}$ & & \\
\hline & $(0.000)$ & $(0.000)$ & $(0.000)$ & $(0.000)$ & $(0.000)$ & & \\
\hline \multirow[t]{2}{*}{ CGl1 } & $0.007^{*}$ & & & & & & \\
\hline & $(0.083)$ & & & & & & \\
\hline \multirow[t]{2}{*}{ CGI2 } & & $0.008^{* \star}$ & & & & & \\
\hline & & $(0.045)$ & & & & & \\
\hline \multirow[t]{2}{*}{ CGI3 } & & & $0.049^{* *}$ & & & & \\
\hline & & & $(0.029)$ & & & & \\
\hline \multirow[t]{2}{*}{ CSRI } & & & & $0.393^{* * *}$ & & $0.043^{*}$ & \\
\hline & & & & $(0.007)$ & & $(0.060)$ & \\
\hline \multirow[t]{2}{*}{ CSRI_PCA } & & & & & $0.168^{* *}$ & & $0.037^{* *}$ \\
\hline & & & & & $(0.037)$ & & $(0.013)$ \\
\hline \multirow[t]{2}{*}{ CGI_CONTR } & & & & $0.005^{*}$ & 0.008 * & $0.005^{* * *}$ & $0.009^{* * *}$ \\
\hline & & & & $(0.081)$ & $(0.084)$ & $(0.000)$ & $(0.000)$ \\
\hline \multirow[t]{2}{*}{ LNTA } & $-0.150^{* * *}$ & $-0.067^{*}$ & $-0.101 * *$ & -0.046 & $-0.342^{* * *}$ & $-0.184^{\star \star \star}$ & $-0.184^{* * *}$ \\
\hline & $(0.001)$ & $(0.084)$ & $(0.042)$ & $(0.222)$ & $(0.000)$ & $(0.000)$ & $(0.000)$ \\
\hline \multirow[t]{2}{*}{ PGSALES } & $0.257^{* \star *}$ & 0.224 ** & 0.201 ** & $0.243^{* * *}$ & $0.354^{\star \star \star}$ & $0.116^{* * *}$ & $0.149^{* * *}$ \\
\hline & $(0.005)$ & $(0.011)$ & $(0.035)$ & $(0.004)$ & $(0.009)$ & $(0.000)$ & $(0.000)$ \\
\hline \multirow[t]{2}{*}{ RD/SALES } & -0.198 & 0.033 & -0.165 & 0.165 & -0.244 & $1.150^{* \star *}$ & $0.684^{* * *}$ \\
\hline & $(0.429)$ & $(0.883)$ & $(0.536)$ & $(0.448)$ & $(0.421)$ & $(0.007)$ & $(0.001)$ \\
\hline \multirow[t]{2}{*}{ CASH/ASSETS } & 1.271 * & 0.684 & $1.510^{* *}$ & 0.491 & -1.286 & $1.211^{* * *}$ & $1.297^{* * *}$ \\
\hline & $(0.063)$ & $(0.245)$ & $(0.041)$ & $(0.415)$ & $(0.136)$ & $(0.000)$ & $(0.000)$ \\
\hline \multirow[t]{2}{*}{ CAPEX/ASSETS } & 1.528 ** & 1.658 ** & $1.503^{* *}$ & $1.453^{* *}$ & -0.287 & $1.171^{* * *}$ & $0.998^{* * *}$ \\
\hline & $(0.026)$ & $(0.011)$ & $(0.029)$ & $(0.023)$ & $(0.677)$ & $(0.000)$ & $(0.007)$ \\
\hline \multirow[t]{2}{*}{ PPE/SALES } & $0.073^{\star \star \star}$ & $0.072^{\star * \star}$ & $0.083^{* * *}$ & $0.063^{* * *}$ & -0.013 & $-0.077^{* * *}$ & $-0.080 * * *$ \\
\hline & $(0.001)$ & $(0.000)$ & $(0.000)$ & $(0.001)$ & $(0.570)$ & $(0.000)$ & $(0.000)$ \\
\hline \multirow[t]{2}{*}{ EBIT/SALES } & -0.434 ** & $-0.499 * * *$ & $-0.649^{* * *}$ & -0.290 & -0.319 & $0.475^{* * *}$ & $0.449^{* * *}$ \\
\hline & $(0.031)$ & $(0.009)$ & $(0.002)$ & $(0.108)$ & $(0.196)$ & $(0.000)$ & $(0.000)$ \\
\hline \multirow[t]{2}{*}{ LEVERAGE } & -0.779 ** & $-0.928^{* \star *}$ & $-1.010^{* * *}$ & $-0.784^{* * *}$ & $-1.481^{* \star *}$ & $0.097^{* *}$ & -0.036 \\
\hline & $(0.014)$ & $(0.002)$ & $(0.001)$ & $(0.004)$ & $(0.000)$ & $(0.026)$ & $(0.315)$ \\
\hline \multirow[t]{2}{*}{ ADR } & $0.265^{*}$ & $0.393^{* * \star}$ & $0.347^{\star \star}$ & $0.348^{* \star \star}$ & 0.271 & $0.162^{* * *}$ & $0.162^{* * *}$ \\
\hline & $(0.073)$ & $(0.003)$ & $(0.030)$ & $(0.007)$ & $(0.134)$ & $(0.000)$ & $(0.000)$ \\
\hline \multirow[t]{2}{*}{ CLOSELY HELD } & -0.005 & -0.002 & -0.003 & 0.001 & $-0.007^{*}$ & $0.004 * * *$ & $0.002^{* * *}$ \\
\hline & $(0.108)$ & $(0.559)$ & $(0.284)$ & $(0.675)$ & $(0.061)$ & $(0.000)$ & $(0.000)$ \\
\hline \multirow[t]{2}{*}{ LAMBDA } & & & & & & $-0.165^{* * *}$ & $-0.071^{* * *}$ \\
\hline & & & & & & $(0.001)$ & $(0.003)$ \\
\hline$p$-value of $A R(1)$ test & 0.002 & 0.001 & 0.002 & 0.000 & 0.000 & - & - \\
\hline$p$-value of $A R(2)$ test & 0.904 & 0.716 & 0.727 & 0.365 & 0.739 & - & - \\
\hline R-squared & - & - & - & - & - & 0.243 & 0.248 \\
\hline Firms & 1,470 & 1,470 & 1,359 & 1,470 & 1,022 & 1,625 & 1,111 \\
\hline Observations & 4,034 & 4,034 & 3,644 & 4,034 & 2,400 & 5,453 & 2,763 \\
\hline
\end{tabular}




\section{Table 9 - continued}

The first five columns of the table report the results from regressions of Tobin's Q on lagged Q, alternative corporate governance and corporate social responsibility indices, and control variables. The regressions are estimated by using a dynamic panel GMM estimator as proposed by Arellano and Bover (1995) and Blundell and Bond (1998). CGI1 denotes the governance index constructed in the same way as Aggarwal et al. (2009), namely by dividing the governance attributes a company fulfills by the number of governance attributes a company reports data for. CGI2 denotes the governance index constructed in the same way as CGI1 but with missing attributes treated as if these attributes were not fulfilled. CGI3 denotes the governance index constructed by means of principal component analysis (PCA). CSRI denotes the CSR index constructed in the same way as CGI2, using the nine CSR attributes and treating missing attributes as if they were not in place. CSRI_PCA denotes the CSR index constructed by means of principal component analysis (PCA), using the nine CSR attributes. CGI_CONTR denotes the governance index constructed of the governance attributes that are not part of the company behavior (CSR) category. LNTA denotes the logarithm of total assets, PGSALES denotes the two-year growth of sales, RD/SALES denotes the ratio of expenditures for research and development to sales, CASH/ASSETS denotes the ratio of cash to total assets, CAPEX/ASSETS denotes the ratio of capital expenditures to assets, PPE/SALES denotes the ratio of property-plants-equipments to sales, EBIT/SALES denotes the ratio of earnings before interest and taxes to sales, LEVERAGE denotes the ratio of total debt to total assets, ADR is a dummy variable which equals 1 if the firm has American Depository Receipts (ADR) and 0 otherwise, CLOSELY HELD is the percentage of closely held shares. All regressions include year fixed effects. Firm fixed effects drop out because the regression is estimated in first differences. $\mathrm{AR}(1)$ and $\mathrm{AR}(2)$ are tests for first-order and second-order serial correlation in the first differenced residuals with the null hypothesis of no serial correlation. The last two columns of the table report the results from a Heckman (1979) self-selection model. The dependent variable of the second-stage regressions is Tobin's Q and we include the same set of explanatory variables as in the GMM regressions reported in Columns 4 and 5 of the table. CSRI and CSRI_PCA are redefined into dummy variables that equal one for firm-years for which the value of CSRI (CSRI_PCA) is larger than the median value. The dependent variable of the first-stage probit regressions (not reported) are these dummy variable indicating whether a firm's CSRI or CSRI_PCA is above the median value. The explanatory variables are based on Harjoto and Jo (2008) and include CGI_CONTR, LNTA, RD/SALES, EBIT/SALES, LEVERAGE, and industry dummy variables. LAMBDA is the self-selection parameter (or inverse Mill's ratio) from the first-stage probit regressions. ${ }^{* *}, * *, *$ denotes statistical significance at the $1 \%, 5 \%, 10 \%$ level. 
Table 10: Individual corporate governance attributes

\begin{tabular}{|c|c|c|c|c|}
\hline Panel A: Corporate governance attributes selected for PCA & Coefficient & $p$-value & Coefficient & $p$-value \\
\hline & \multicolumn{2}{|l|}{ (1) } & \multicolumn{2}{|l|}{ (2) } \\
\hline Company has a designated "lead" or senior non-executive board member & -0.012 & 0.531 & -0.023 & 0.403 \\
\hline No former CEO of the company serves on the board & 0.002 & 0.799 & 0.014 & 0.220 \\
\hline Board size is greater than five but less than 16 & $0.062^{* * *}$ & 0.000 & $0.057^{* * *}$ & 0.000 \\
\hline Company has not had a material earnings restatement in the past three years & -0.011 & 0.697 & -0.020 & 0.474 \\
\hline Company has not received a qualified audit opinion within the last two fiscal years & $0.331^{\star \star \star}$ & 0.000 & $0.341^{* * *}$ & 0.000 \\
\hline Board members are subject to annual election by all shareholders & 0.020 & 0.202 & 0.010 & 0.563 \\
\hline No single shareholder or shareholder group with majority of voting power & 0.013 & 0.668 & -0.008 & 0.829 \\
\hline All common or ordinary equity shares have one-share, one-vote, with no restrictions & $0.046^{\star \star \star}$ & 0.021 & $0.044^{* *}$ & 0.048 \\
\hline Company discloses its corporate governance policies or guidelines & $0.065^{* *}$ & 0.029 & $0.057^{*}$ & 0.080 \\
\hline Voting rights are not capped at a certain percentage & -0.060 & 0.549 & -0.067 & 0.475 \\
\hline Company allows cumulative voting in the election of directors & 0.009 & 0.654 & -0.022 & 0.130 \\
\hline Shareholders have a right to convene an EGM & $0.182^{* * *}$ & 0.000 & $0.178^{* * *}$ & 0.000 \\
\hline Company does not have a staggered ("classified") board & -0.047 & 0.127 & -0.064 * & 0.083 \\
\hline Company does not require a supermajority vote to approve a merger & $-0.092^{* * *}$ & 0.000 & $-0.010^{* * *}$ & 0.000 \\
\hline Audit committee is wholly composed of independent board members & $0.073^{* * *}$ & 0.000 & $0.051^{* * *}$ & 0.000 \\
\hline There have been no related-party transactions in the past three years & 0.001 & 0.984 & -0.011 & 0.367 \\
\hline Board is controlled by more than $50 \%$ of independent outside directors & $0.046^{\star \star \star}$ & 0.001 & 0.018 & 0.189 \\
\hline \multicolumn{5}{|l|}{ Panel B: Governance attributes pertaining to corporate social responsibility } \\
\hline Company has a policy addressing workplace safety & -0.001 & 0.914 & 0.005 & 0.737 \\
\hline Company does not have pending criminal litigation against it & 0.026 & 0.264 & $0.049^{* * *}$ & 0.002 \\
\hline No allegation that company used sweat shops within the last three years & 0.015 & 0.346 & 0.032 & 0.101 \\
\hline Company discloses its environmental performance & 0.007 & 0.503 & $0.024^{* *}$ & 0.037 \\
\hline Company discloses its workplace safety record & $0.025^{*}$ & 0.074 & $0.037^{* * *}$ & 0.006 \\
\hline No regulatory investigation for a material issue other than accounting irregularities & $0.041^{* * *}$ & 0.001 & $0.044^{* * *}$ & 0.003 \\
\hline Company discloses its policy regarding corporate level political donations & $0.063^{* * *}$ & 0.000 & $0.063^{* * *}$ & 0.000 \\
\hline Company has not been charged with workplace safety violations & $0.064^{* * *}$ & 0.000 & $0.058^{* * *}$ & 0.000 \\
\hline It has not been alleged that the company uses child labor & -0.018 & 0.452 & -0.014 & 0.624 \\
\hline
\end{tabular}

Panel A of the table reports the results from fixed effects regressions of Tobin's Q on individual governance attributes and control variables. The 17 attributes correspond to those included in the basic principal component analysis used to construct CGI3. Panel B of the table reports the results from fixed effects regressions of Tobin's Q on individual CSR attributes. Each attribute of GMI's corporate behavior category is included. In Column 1, each attribute is individually included in the regression, in Column 2 all attributes are included jointly. In the regressions using CSR attributes, we additionally include the control variable CGI CONTR. The $p$ values (in parentheses) are based on Driscoll and Kraay (1998) standard errors which are heteroskedasticity-consistent and robust to general forms of cross-sectional and temporal dependence. $* * *, * *, *$ denotes statistical significance at the $1 \%, 5 \%, 10 \%$ level. 
Table 11: Survey of previous research on the valuation effect of corporate governance

\begin{tabular}{|c|c|c|c|c|c|c|c|}
\hline Paper & Country/countries & Sample period & $\begin{array}{r}\text { Observations / } \\
\text { firms }\end{array}$ & $\begin{array}{l}\text { Governance } \\
\text { data source }\end{array}$ & $\begin{array}{r}\text { \# of governance } \\
\text { attributes in index }\end{array}$ & Estimation approach(es) & Economic effect \\
\hline Gompers, Ishii, and Metrick (2003) & USA & 1990-1999 & $\mathrm{NA} / 1,500$ & IRRC (RiskMetrics) & 24 & OLS & $\begin{array}{r}\text { An increase in the G-index by one } \\
\text { standard deviation (2.8) leads to } \\
\text { a decrease in } \mathrm{Q} \text { by } 0.120^{\mathrm{a}}\end{array}$ \\
\hline Klapper and Love (2004) & 14 Emerging markets & 2000 & 374 & $\begin{array}{r}\text { Credit Lyonnais } \\
\text { Securities Asia (CSLA) }\end{array}$ & 57 & OLS & $\begin{array}{r}\text { An increase in the gov. index by one } \\
\text { standard deviation (14.0) leads to an increase } \\
\text { in Q by } 0.322 \text { ( } 15 \% \text { of mean, } 23 \% \text { of median } Q \text { ) }\end{array}$ \\
\hline Durnev and Kim (2005) & $\begin{array}{l}24 \text { Developed and } \\
\text { emerging countries }\end{array}$ & 2000 & 494 & $\begin{array}{r}\text { Credit Lyonnais } \\
\text { Securities Asia (CSLA) }\end{array}$ & 57 & $\begin{array}{r}\text { OLS / 3SLS (system of two } \\
\text { simultaneous equations) }\end{array}$ & $\begin{array}{r}\text { An increase in the gov. index by one } \\
\text { standard deviation (8.99) leads to an } \\
\text { increase in Q by } 0.175 \text { ( } 9 \% \text { relative to mean } Q \text { ); } \\
\text { 3SLS increases the effect to } 0.421 \text { ( } 22 \% \text { of } \text { ) }\end{array}$ \\
\hline Brown and Caylor (2006) & USA & 2002 & 1,868 & $\begin{array}{r}\text { Institutional Shareholder } \\
\text { Services (ISS) }\end{array}$ & 51 & OLS & $\begin{array}{r}\text { An increase in the governance index by one } \\
\text { standard deviation (3.45) leads to an increase } \\
\text { Q by } 0.11 \text {, i.e., } 6.6 \%(9.1 \%) \text { of mean (median) Q }\end{array}$ \\
\hline $\begin{array}{l}\text { Aggarwal, Erel, Stulz, } \\
\text { and Williamson (2009) }\end{array}$ & $\begin{array}{r}23 \text { developing countries } \\
\text { (incl. US) }\end{array}$ & 2005 & 1,527 & $\begin{array}{r}\text { Institutional Shareholder } \\
\text { Services (ISS) }\end{array}$ & 44 & OLS / Instrumental variable & $\begin{array}{r}\text { Increasing the gov. index by the average } \\
\text { gap to matched U.S. firms increases Q by } 0.094, \\
\text { an increase of } 6.2 \% \text { of median Q }\end{array}$ \\
\hline Chhaochharia and Laeven (2009) & $\begin{array}{r}23 \text { developing countries } \\
\text { (incl. US) }\end{array}$ & 2003-2005 & $\begin{array}{r}6,134 \text { firm-years } \\
>2,300 \text { firms }\end{array}$ & $\begin{array}{r}\text { Institutional Shareholder } \\
\text { Services (ISS) }\end{array}$ & 17 & $\begin{array}{l}\text { Panel regression with } \\
\text { fixed effects (OLS); } \\
\text { GMM (Arellano/Bond) }\end{array}$ & $\begin{array}{l}\text { A one standard deviation increase in the gov. } \\
\text { index is associated with a } 0.07 \text { increase in } Q \text {, } \\
\text { which is } 4.4 \%(5.5 \%) \text { of mean (median) Q } \\
\text { GMM leads to a substantially larger effect }\end{array}$ \\
\hline Cremers and Ferrell (2010) & USA & $1978-2006$ & $\begin{array}{r}23,296 \text { firm years } \\
\text { approx. 1,000 firms }\end{array}$ & $\begin{array}{r}\text { IRRC (RiskMetrics), } \\
\text { Handcollected } \\
(10-\mathrm{K}, 10-\mathrm{Q}, \text { proxy) }\end{array}$ & 24 & $\begin{array}{r}\text { Panel regression with } \\
\text { fixed effects (OLS) }\end{array}$ & $\begin{array}{r}\text { An increase in the G-Index by one standard } \\
\text { deviation (3) leads to a decrease in } Q \text { by about } \\
0.033 \text {, a reduction of } 2.1 \% \text { of mean } Q^{a}\end{array}$ \\
\hline
\end{tabular}

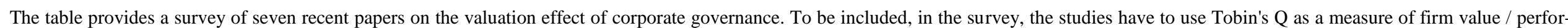

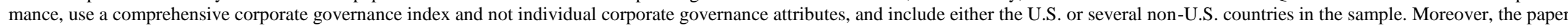

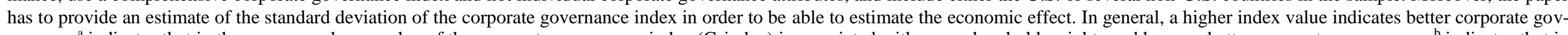

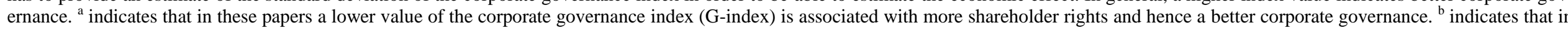

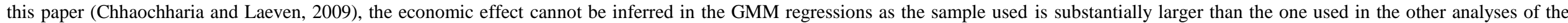
paper and the corresponding descriptive statistics of the extended sample are not reported. 
Figure 1: Empirical distribution of governance scores for CGI1 and CGI2

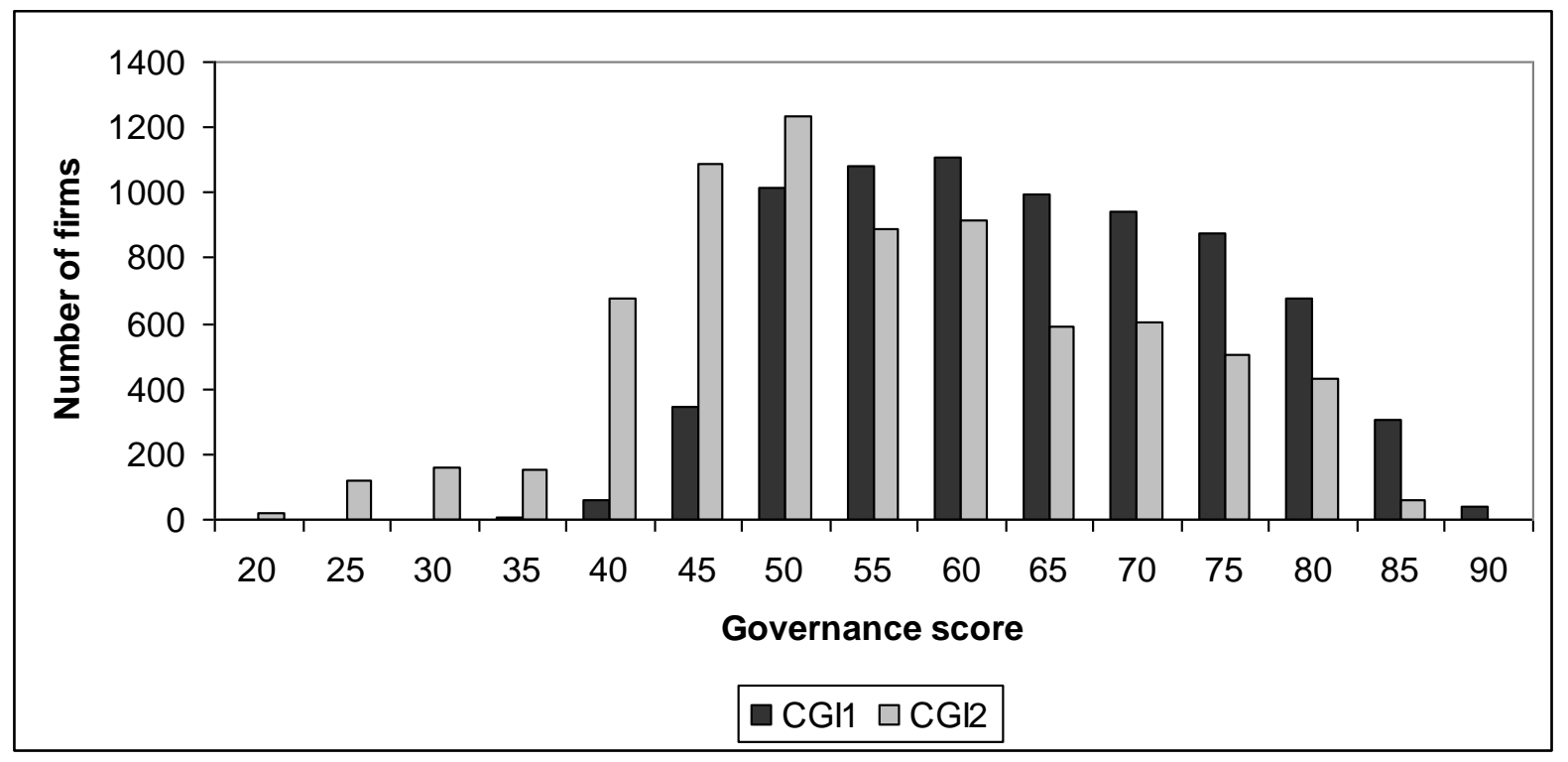

The figure shows the distribution of our two additively constructed corporate governance indices, CGI1 and CGI2. Dark grey represents the scores according to CGI1, light grey represents the scores according to CGI2. CGI1 denotes the governance index constructed in the same way as Aggarwal et al. (2009), namely by dividing the governance attributes a company fulfills by the number of governance attributes a company reports data for. CGI 2 denotes the governance index constructed in the same way as CGI1 but with missing attributes treated as if these attributes were not fulfilled. 